\title{
Article \\ Coiled-Coil N21 of Hpa1 in Xanthomonas oryzae pv. oryzae Promotes Plant Growth, Disease Resistance and Drought Tolerance in Non-Hosts via Eliciting HR and Regulation of Multiple Defense Response Genes
}

\author{
Zhao-Lin Ji ${ }^{1}$, Mei-Hui Yu ${ }^{2}$, Ya-Yan Ding ${ }^{1}$, Jian Li ${ }^{1}$, Feng Zhu ${ }^{1}$, Jun-Xian He ${ }^{2, *}$ and Li-Na Yang ${ }^{1, *}$ \\ 1 College of Horticulture and Plant Protection, Yangzhou University, Yangzhou 225009, China; \\ zhlji@yzu.edu.cn (Z.-L.J.); ydnwkxk@163.com (Y.-Y.D.); yz_lijian@163.com (J.L.); zhufeng@yzu.edu.cn (F.Z.) \\ 2 School of Life Sciences and State Key Laboratory of Agrobiotechnology, The Chinese University of Hong \\ Kong, Shatin, New Territories, Hong Kong, China; cketnn7@hotmail.com \\ * Correspondence: jxhe@cuhk.edu.hk (J.-X.H.); linayang0909@163.com (L.-N.Y.)
}

\section{check for} updates

Citation: Ji, Z.-L.; Yu, M.-H.; Ding, Y.-Y.; Li, J.; Zhu, F.; He, J.-X.; Yang, L.-N. Coiled-Coil N21 of Hpa1 in Xanthomonas oryzae pv. oryzae Promotes Plant Growth, Disease Resistance and Drought Tolerance in Non-Hosts via Eliciting HR and Regulation of Multiple Defense Response Genes. Int. J. Mol. Sci. 2021, 22, 203. https://dx.doi.org/10.3390/ ijms22010203

Received: 13 December 2020 Accepted: 24 December 2020 Published: 28 December 2020

Publisher's Note: MDPI stays neutral with regard to jurisdictional claims in published maps and institutional affiliations.

Copyright: () 2020 by the authors. Licensee MDPI, Basel, Switzerland. This article is an open access article distributed under the terms and conditions of the Creative Commons Attribution (CC BY) license (https: / / creativecommons.org / licenses/by/4.0/).

\begin{abstract}
Acting as a typical harpin protein, Hpa1 of Xanthomonas oryzae pv. oryzae is one of the pathogenic factors in hosts and can elicit hypersensitive responses (HR) in non-hosts. To further explain the underlying mechanisms of its induced resistance, we studied the function of the most stable and shortest three heptads in the N-terminal coiled-coil domain of Hpa1, named N21 $1_{\mathrm{Hpa}}$. Proteins isolated from N21-transgenic tobacco elicited HR in Xanthi tobacco, which was consistent with the results using N21 and full-length Hpa1 proteins expressed in Escherichia coli. N21-expressing tobacco plants showed enhanced resistance to tobacco mosaic virus (TMV) and Pectobacterium carotovora subsp. carotovora $(P c c)$. Spraying of a synthesized N21 peptide solution delayed the disease symptoms caused by Botrytis cinerea and Monilinia fructicola and promoted the growth and drought tolerance of plants. Further analysis indicated that N21 upregulated the expression of multiple plant defense-related genes, such as genes mediated by salicylic acid (SA), jasmonic acid (JA) and ethylene (ET) signaling, and genes related to reactive oxygen species (ROS) biosynthesis. Further, the bioavailability of $\mathrm{N} 21$ peptide was better than that of full-length $\mathrm{Hpa}{ }_{\mathrm{Xoo}}$. Our studies support the broad application prospects of N21 peptide as a promising succedaneum to biopesticide Messenger or Illite or other biological pharmaceutical products, and provide a basis for further development of biopesticides using proteins with similar structures.
\end{abstract}

Keywords: $\mathrm{N}^{2} 1_{\mathrm{Hpa}} ; \mathrm{HR}$; disease resistance; growth promotion; drought tolerance

\section{Introduction}

Harpin proteins are virulence factors in susceptible plants, translocators for effectors, elicitors of hypersensitive response (HR), inducers of defense responses and enhancers of plant growth in non-host plants [1-9]. Hpa1 is one of the harpin proteins that is secreted via type III secretion systems into the extracellular spaces of plant cells $[1,4,10,11]$.

Hpa1 of the Gram-negative bacteria Xanthomonas oryzae pv. oryzae which causes the bacterial blight of rice consists of 139 amino acids with two predicted $\alpha$-helices at the N-terminal (36-53 aa) and C-terminal (87-103 aa), respectively, and has a high glycine content, particularly in the middle and C-terminal $[4,9,12]$. The functions of the different domains of some harpin proteins have been studied. The N-terminal of Hpa1 $1_{\text {Xo }}$ has bioactivities, including inducing resistance and promoting growth in tobacco, and leaf photosynthesis in Arabidopsis [12-16]. N-terminals that lacked 36 amino acids or lacking one or two of the $\alpha$-helices of Hpa $1_{\text {Xoo }}$ exhibit reduced virulence, and both $\alpha$-helices play a critical role in the translocation of transcription activator-like (TAL) effectors [9]. The $\alpha$-helix of the N-terminal of HpaG of X. axonopodis pv. glycines is essential for eliciting an HR in tobacco [17]. The C-terminal 216 amino acids of HrpZ of Pseudomonas syringae pv. 
syringae, 200-300 residues of HrpZ of P. syringae pv. phaseolicola and C-terminal 21 residues of Hpa1 Xoo could also elicit a strong HR [12,18,19]. However, the coiled-coil (CC) regions in the N-terminal and C-terminal of Hpa1 $\mathrm{Xoo}_{\mathrm{Xo}}$ have the opposite functions: CC-formation in the $\mathrm{N}$-terminal could induce HR but CC-formation in the C-terminal could not, since only a polymerized CC structure could cause HR [12].

CC domains consist of two or more $\alpha$-helices that interact with each other to form supercoiled bundles via "knobs-into-holes" (KIH) interactions [20-22]. Typical CC domains are contiguous heptad repeats (seven amino acids repeats), often defined as abcdefg, in which the $a$ and $d$ hydrophobic residues provide driving forces for intertwining, and influence the oligomerization of the helices [23-25]. The $e$ and $g$ sites balance the opposing forces of the $\alpha$-helices and maintain the stability and oligomerization of the structure [26,27]. Two heptads could form high degree of $\alpha$-helices and $100 \%$ dimers in the corresponding buffers. However, the oligomerization state may change from dimers to trimers with increasing ionic strength $[28,29]$. Therefore, three heptads are the shortest sequences to stabilize CC folding. CC domains are important assembly units in a variety of structures and regulatory proteins in eukaryotes and prokaryotes, such as transcription regulators, membrane sensors and skeletal proteins [26,30,31]. Furthermore, our previous work has indicated that CC domains play essential roles in structure of Xanthomonas Hpa1 protein which could induce HR in non-host. Three heptads of the $\alpha$-helix in the N-terminal of Hpa1 $\mathrm{Xoo}_{\mathrm{oo}}$, named N21, form a coiled-coil domain that was a mixture of dimers and monomers and induced strong HR in tobacco. Trimers of 21 aa in the C-terminal of $\mathrm{Hpa}_{\mathrm{X}_{\mathrm{oo}}}$ induce relatively minor HR in tobacco, but it has a lower probability to form CC region [12]. Wang and his colleagues have showed that mutation of 12 highly hydrophilic amino acids in the N-terminal of $\mathrm{Hpa}_{\mathrm{X}_{\mathrm{oo}}}$ abolished the ability of $\mathrm{Hpa}_{\mathrm{X}_{\mathrm{oo}}}$ to elicit HR in tobacco and that these conserved amino acids played critical roles in protein aggregation [13,32]. All these evidences suggest that $\mathrm{N}$-terminal of $\mathrm{Hpa}_{\mathrm{X}_{\mathrm{oo}}}$ and formation of $\mathrm{CC}$ domain are important for protein function. Therefore, we focused our research on coiled-coil 21 amino acids at the N-terminal of $\mathrm{Hpa} 1_{\chi_{\mathrm{oo}}}$.

Harpin proteins, as Messenger from Erwinia amylowora, that was popularized by US environmental protection agency, and Illite from Xanthomonas oryzae pv. oryzicola (Xoc), that was studied in a plant pathology laboratory in Nanjing Agriculture University, were developed as biopesticides, because of their promoting effects on plant growth, crop yield, plant disease resistance, non-toxicity, no residue and environmental friendliness. However, poor bioavailability was the major constraining factor for the use of harpins as biopesticides because few harpin molecules interacted with receptors due to the particular structure of plant leaves. Podile and co-workers wrapped harpin ${ }_{\text {Pss }}$ in chitosan nanoparticles to improve its bioavailability and disease resistance in tomato [33].

$\mathrm{N} 21_{\mathrm{Hpa} 1}$ induced HR in tobacco, as effective as the full-length $\mathrm{Hpa} 1_{\mathrm{Xoo}_{\mathrm{o}}}$, thus we wanted to learn more about the function of N21 to see if it could be used as a succedaneum to Hpa1 ${ }_{\mathrm{Xoo}}$. Results of the present work suggested that protein of transgenic-N21 tobacco plants retained sufficient activity to elicit HR. N21-expressing tobacco plants enhanced the resistance to tobacco mosaic virus (TMV) and Pectobacterium carotovora subsp. carotovora $(P c c)$. The application of an N21 peptide solution to some plants induced several beneficial effects, including improvement of host resistance to Botrytis cinerea and Monilinia fructicola, promotion of plant growth, enhancement of drought tolerance that is even better than that of the full-length protein. In addition, N21-induced multiple defense responses in transgenic-N21 tobacco and had a better bioavailability.

\section{Results}

\subsection{Generation of Transgenic-N21 Tobacco and Trans-N21 Protein Activity Assay}

The expression vector was constructed in the digested skeleton of pBI121 using the cDNA sequences of N21 (Figure 1A). The constructed vector was first transformed into Agrobacterium strain EHA105 and then co-cultured with tobacco plants by the leaf disc method (Supplementary Materials Figure S1). The progeny of transgenic tobacco was 
sub-cultured to the T3 generation to screen for recombinant protein expressing plants via kanamycin resistance and further verified by using PCR (Figure S2) and semi-quantitative RT-PCR (Figure S3). The selected T3 plants were further screened for homozygotes. Phenotypic observation on the selected N21- and Hpa1-expressing tobacco plants showed that the transgenic plants grew much bigger than the control plants transformed with the empty vector (EV or $p B I 121$-expressing) (Figure 1B). Root length of the trans-N21 tobacco was $\sim 1.3$-fold higher than that of EV-ones and $~ 0.8$-fold lower than that of trans-Hpa1 plants (Figure 1E). The plant height of trans-N21 tobacco was $\sim 0.8$-fold that of the full-length transgenic tobacco, and $~ 1.5$-fold of the EV tobacco (Figure 1F). The fresh weight of transN21 was $\sim 2.5$-fold of that of EV and $\sim 0.7$-fold of trans-Hpa1 tobacco (Figure 1G). Total protein extracts from the N21-expressing tobacco were injected back into WT Xanthi tobacco plants. Equivalent amount of N21 and Hpa1 proteins expressed directly in Escherichia coli (E. coli) were used as the positive control. Results showed that the N21 protein expressed in trans-N21 tobacco retained sufficient activity to induce HR in Xanthi tobacco. However, the activity was lower than the Hpa1 and N21 proteins expressed by E. coli (Figure 1C). The lower activity might be due to the lower concentration of N21 in trans-N21 tobacco. The measured diameters of HR activity zones were consistent with the above results (Figure 1D).

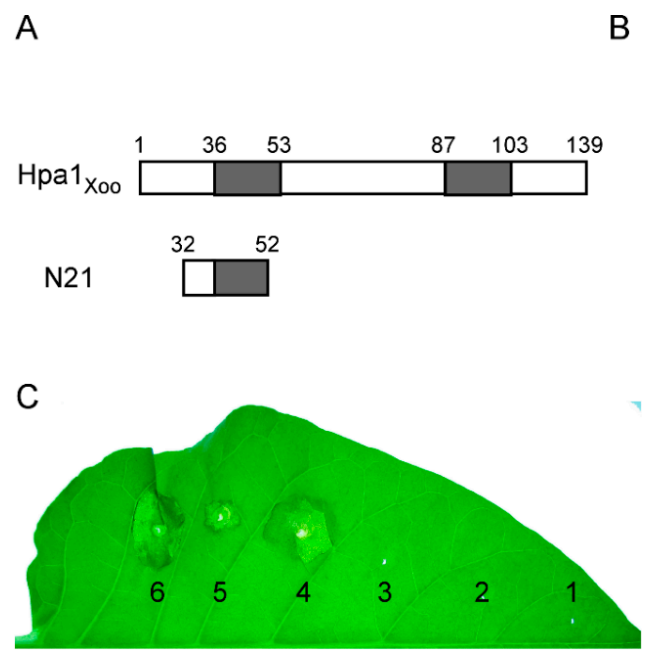

B EV
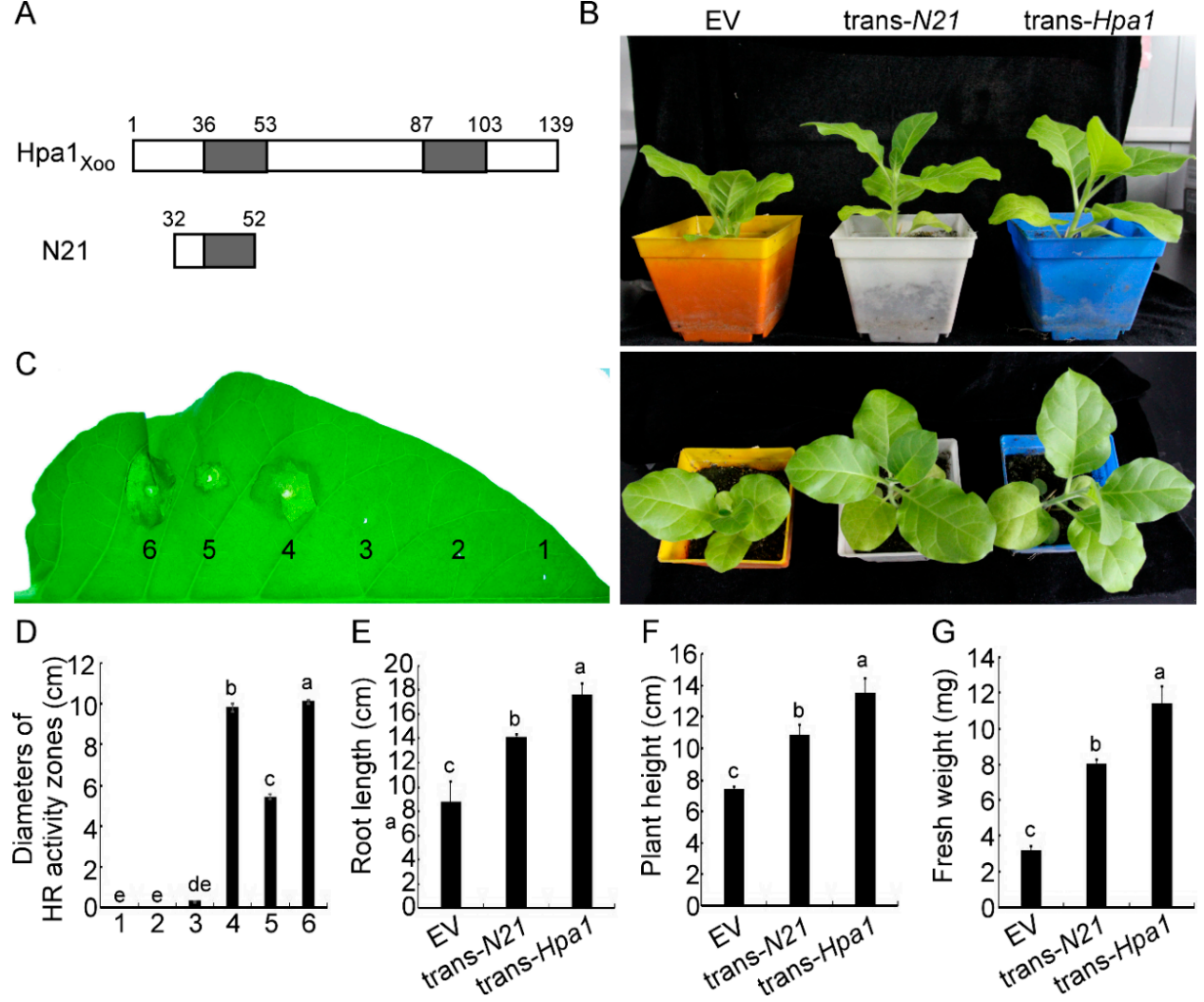

Figure 1. Growth measurement and protein activity assay of trans-N21 tobacco plants in T3 generation. (A) Hpa1-N21 $\mathrm{Xoo}_{\mathrm{oo}}$ was composed of three heptads repeats, which included part of the $\alpha$-helix region. Grey area represents $\alpha$-helix regions. (B) The trans- $\mathrm{N} 21$, trans-Hpa1 and EV tobacco plants were placed in a greenhouse at $25^{\circ} \mathrm{C}$ ( $\mathrm{RH} 80 \%$ ) with alternating light and dark at $16 \mathrm{~h} / 8 \mathrm{~h}$, and photos were taken 45 days after planting. EV represented transgenic empty vector (pBI121) tobacco. (C) Proteins of trans-N21 tobacco induced hypersensitive response (HR) in Xanthi tobacco. Treatments were infiltrated (from right to left): 1. Water; 2. proteins of Xanthi tobacco; 3. proteins of EV tobacco; 4. proteins of N21 expressed by Escherichia coli BL21 cells; 5. proteins of trans-N21 tobacco of T3 progeny; 6. proteins of Hpa1 expressed by E. coli BL21 cells. All protein contents were $5 \mathrm{mg}$. (D) Diameters of HR activity zones were measured at $24 \mathrm{~h}$ post inoculation. Measurements of (E) root length, (F) plant height and (G) fresh weight were taken at 45 days after planting. Error bars represent the standard deviation and letters represent significant differences (Duncan's new multiple range test, $p<0.05$ ). Empty vector expressing tobacco strains (EV) represented transgenic empty vector ( $p$ BI121) tobacco. 


\subsection{N21-Expressing Tobacco Showed Enhanced Resistance to TMV and Pcc}

The resistance of tobacco to TMV can be rapidly induced by harpin with a stable defense response. Therefore, this response is usually used as a basic index of plant disease resistance induced by harpin proteins [12,34]. We investigated whether N21 had a similar function. TMV was inoculated on different transgenic tobacco leaves and the disease symptoms were observed at 36 and $72 \mathrm{~h}$ post inoculation (hpi). The results showed that the number of lesions on N21- and Hpa1-expressing tobacco were significantly reduced compared to the EV tobacco at $36 \mathrm{hpi}$, and the disease resistance reflected by the lesion reduction rate was $70.5 \%$ (N21) and 72.3\% (Hpa1), respectively. At $72 \mathrm{hpi}$, the trans-N21 and trans-Hpa 1 plants had $75.1 \%$ and $80.9 \%$ of the lesion reduction rate, respectively, compared to the EV plants (Figure 2A and Table 1). The results of virus content assays in diseased tobacco leaves showed that the content of TMV was the least in trans-N21 tobacco at $36 \mathrm{hpi}$, with no significant difference between trans-N21 and trans-Hpa1 plants at $72 \mathrm{hpi}$, both showing lower virus contents than that in EV tobacco (Figure 2B). These results indicate that N21-expressing tobacco had also improved resistance to TMV and that the resistance level was higher than that of transgenic tobacco expressing the full-length Hpa1 at the early stage of infection.

A

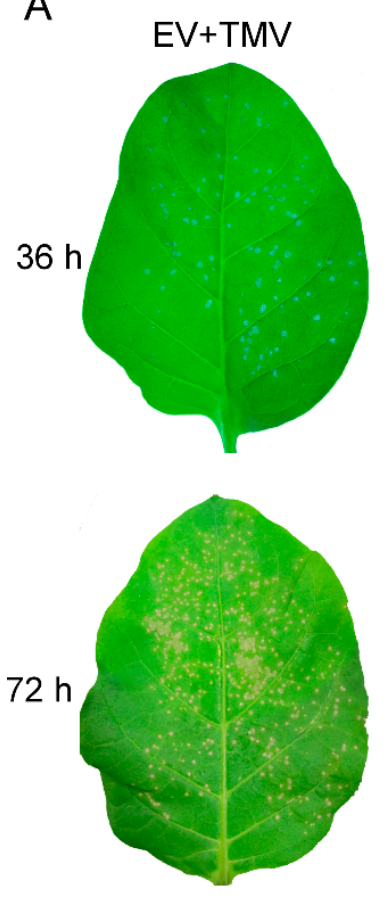

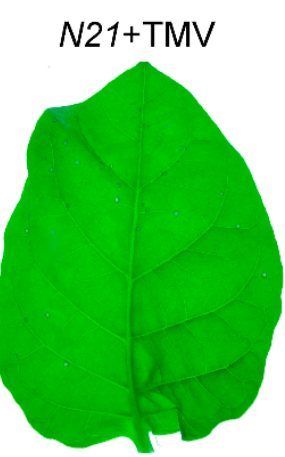

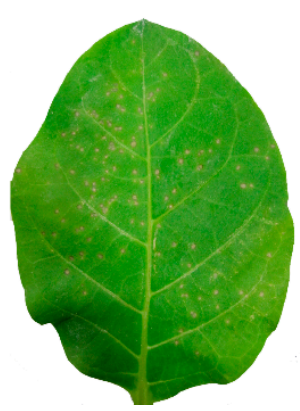

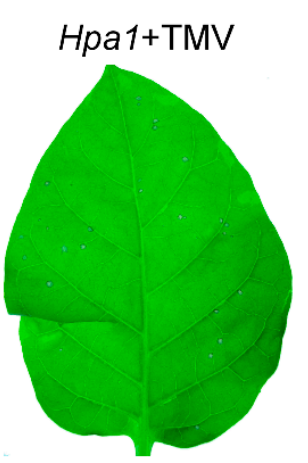

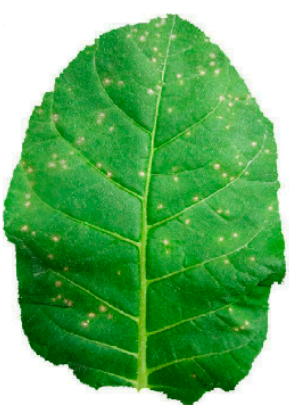

B

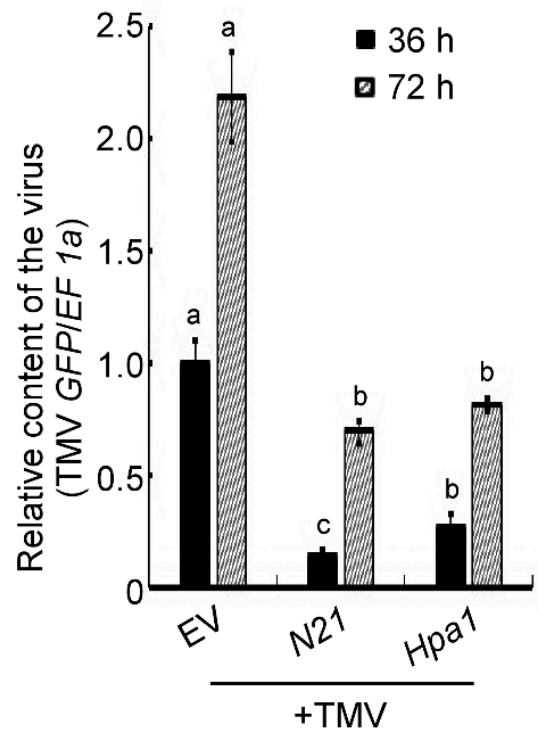

Figure 2. Trans-N21 tobacco showed enhanced resistance to tobacco mosaic virus (TMV). (A) Disease symptoms produced on 8-week different transgenic tobacco strains treated with a TMV suspension $(10 \mu \mathrm{L})$ via friction vaccination at 36 or $72 \mathrm{~h}$ post inoculation (hpi). (B) Relative content of virus in the diseased leaves of EV, N21 and Hpa1 tobacco were measured by quantifying TMV GFP relative to tobacco genomic EF $1 \alpha$ at 36 or $72 \mathrm{hpi}$. Error bars represent the standard deviation and letters represent significant differences (Duncan's new multiple range test, $p<0.05$ ). EV, N21, Hpa1 represented transgenic empty vector tobacco, trans-N21 tobacco and trans-Hpa1 tobacco, separately.

Pectobacterium carotovora subsp. carotovora $(P c c)$ is a pathogenic-bacteria that spreads through plant leaf veins to cause disease. The leaves of different transgenic tobacco plants were impregnated with a suspension of $P c c$ and compared with plants immersed in water. At $12 \mathrm{hpi}$, we did not see any differences between the Pcc-and water-treated plants either in the trans-N21 or trans-Hpa1 plants. However, bacteria were detected by quantitative real-time PCR (qRT-PCR) in N21- and Hpa1-transgenic tobacco, and found that the content of Pcc in trans-N21 tobacco was the lowest one as compared with that 
in EV and trans-Hpa1 tobacco and the differences were significant. Meanwhile, the main vein and some vein branches of EV plants became bigger differences (Figure 3A,B, white arrows). The differences at $16 \mathrm{hpi}$ were larger than at earlier times, since most leaf veins of EV plants exhibited obvious soft rot, but trans-N21 and trans-Hpa1 plants only had a small portion of watery veins (Figure 3A). The results of bacteria content assay showed a similar trend (Figure 3B). These results suggest that both trans-N21 or trans-Hpa1 plants inhibited the infection rate of $P c c$ via leaf veins of tobacco and thus enhanced the resistance to Pcc.

Table 1. Resistance levels of transgenic tobacco to TMV.

\begin{tabular}{ccc}
\hline Tobacco Strains & Number of Lesions ${ }^{\mathbf{a}}$ & Number of Lesions $^{\mathbf{b}}$ \\
\hline EV & $112 \pm 11.0$ & $462 \pm 34$ \\
trans-N21 & $33 \pm 5.0^{*}$ & $115 \pm 25^{*}$ \\
trans-Hpa1 & $31 \pm 8.0^{*}$ & $88 \pm 23^{*}$ \\
\hline
\end{tabular}

Number of lesions on different transgenic tobacco inoculated with tobacco mosaic virus (TMV) at $36\left(^{a}\right)$ and $72 \mathrm{~h}$ post inoculation (hpi) $\left({ }^{b}\right)$. $\pm \mathrm{SD}$ was calculated from three repeated experiments and asterisks indicate statistically significant differences (Duncan's new multiple range test, ${ }^{*}$ means $p<0.05$ ). EV represents tobacco strains expressing the pBI121 vector.

A
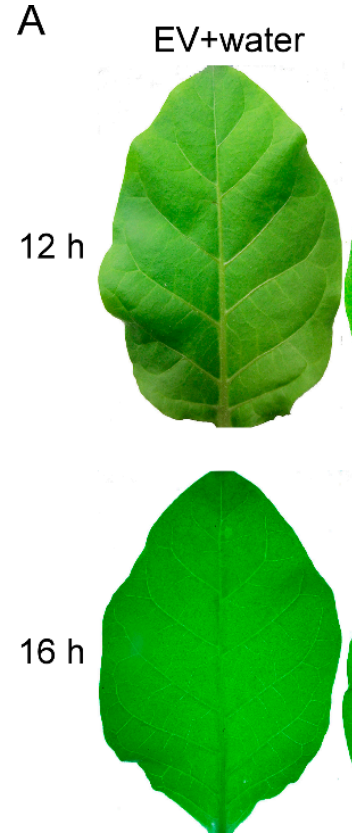
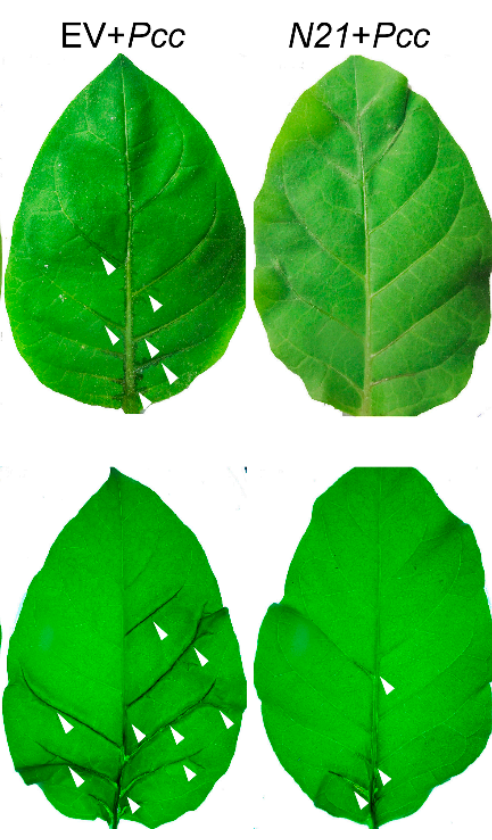

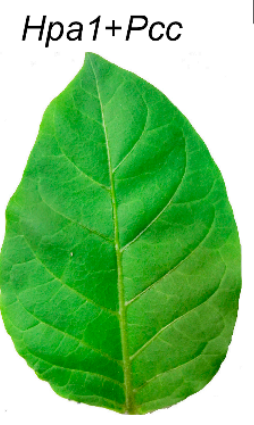

B

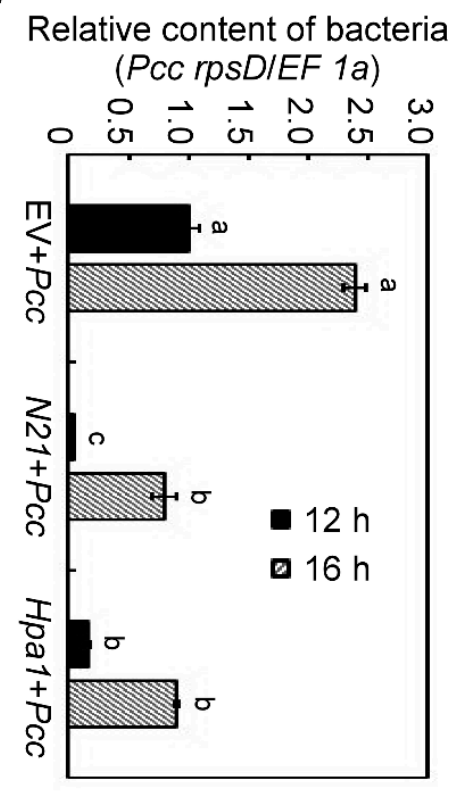

Figure 3. Trans-N21 tobacco has enhanced resistance to Pectobacterium carotovora subsp. carotovora (Pcc). (A) Disease symptoms produced on 8-week different transgenic tobacco strains dipped in suspensions of Pcc at 12 or $16 \mathrm{~h}$ post inoculation (hpi). Treatment with water on EV tobacco was the negative control. The white arrow indicated the affected area. (B) Relative contents of bacteria in the diseased leaves of EV, N21 and Hpa1 tobacco were measured by quantifying $P c c$ rpsD relative to tobacco genomic EF $1 \alpha$ at 12 or 16 hpi. Error bars represent the standard deviation and letters represent significant differences (Duncan's new multiple range test, $p<0.05$ ). EV, N21, Hpa1 represented transgenic tobacco expressing the empty vector, N21or Hpa1protein, separately.

\subsection{Treatment with a N21 Peptide Solution Increased Host Resistance to M. fructicola and B. cinerea}

Based on the increased resistance of the N21-expressing tobacco to TMV and Pcc, we synthesized and purified the N21 peptide, via F-moc synthesis, in order to further study the function of N21. We measured the resistance of peach plants to Monilinia fructicola, a pathogen that causes peach brown rot. The peach plants were pre-treated with different solutions for $24 \mathrm{~h}$, including water, a N21 peptide solution (N21-PS) at the concentration of $40 \mu \mathrm{g} / \mathrm{mL}$, and procymidone $(\sim 0.5 \mathrm{mg} / \mathrm{mL})$ (a prevention agent of peach brown rot. Fol- 
lowing each pre-treatment, hyphal blocks of $M$. fructicola were inoculated on the wounded surface of the peach and the incidences were observed at different time points. The results showed that peaches treated with sterile water showed the largest rotting area and mildew growth at 24 hpi. Plants treated with procymidone exhibited minor decay, with $38.2 \%$ inhibition of the pathogen, and the plants treated with the N21-PS exhibited the smallest rotting area at $24 \mathrm{hpi}$, with an inhibition rate of $59.6 \%$. With the extension of inoculation time (72 hpi), the entire fruit of the water-treated peach was invaded by M. fructicola with abundant mycelia. However, for plants treated with N21-PS, $~ 36.7 \%$ of the peach area was rotten with distinct hyphae. In plants treated with procymidone, about $\sim 52.7 \%$ of the peach area were infected by mycelia of $M$. fructicola (Figure 4A,B). These results indicate that the N21 peptide was more effective in inhibiting the brown rot of peach compared to procymidone.

A

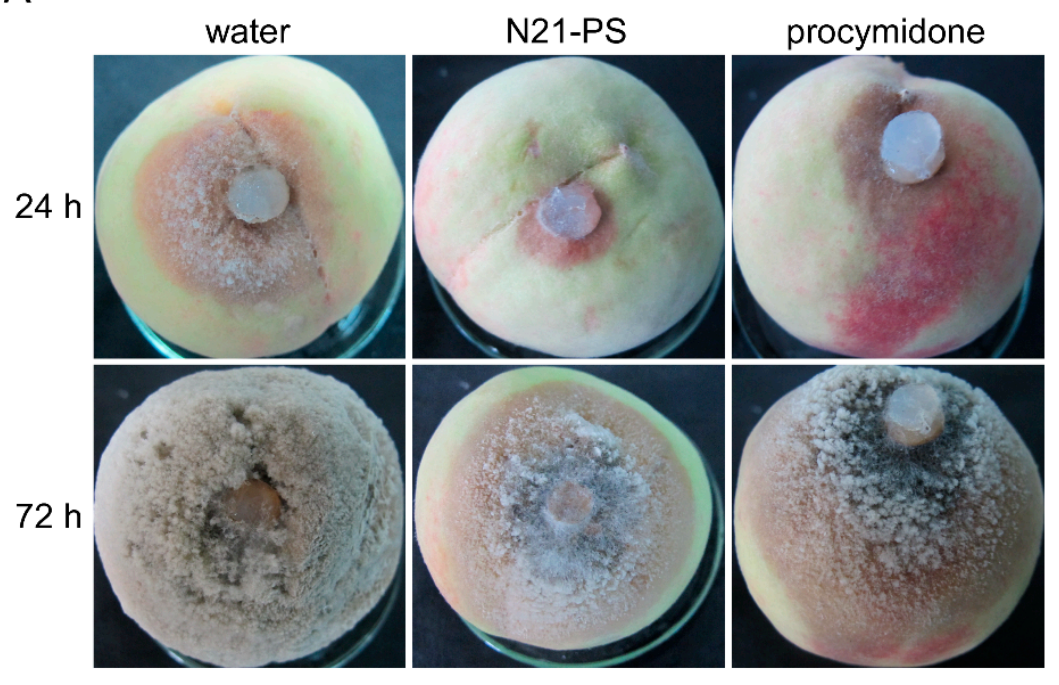

B

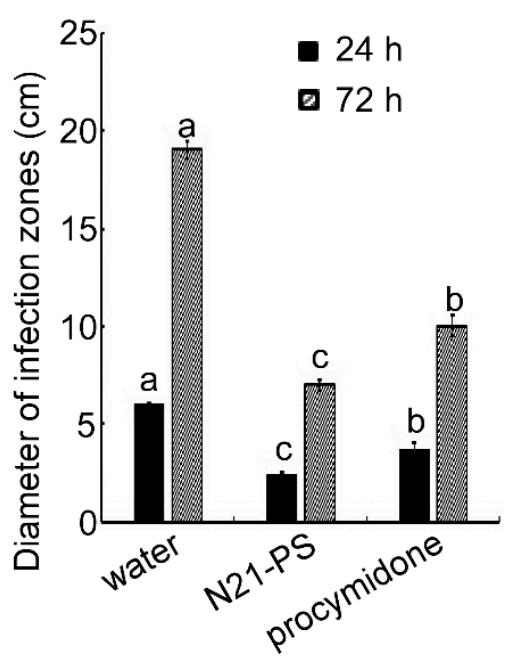

Figure 4. N21 peptide induces host resistance to peach brown rot. (A) Peaches were disinfected with 75\% alcohol, washed with sterile water and dried in a cool place. They were divided into three groups: the first group was sprayed with sterile water; the second group was sprayed with a N21 peptide solution (N21-PS) $(40 \mu \mathrm{g} / \mathrm{mL})$; the third group was sprayed with 1000 times diluted procymidone. Peaches were cultured in an incubator with $13 \mathrm{~h}$ continuous light at $25^{\circ} \mathrm{C}$ with a relative humidity of $50 \%$ and removed after $24 \mathrm{~h}$. Hyphal blocks of $M$. fructicola were inoculated on the wounded surface of peaches with different treatments. Incidences were observed every $24 \mathrm{~h}$ under the same environmental conditions, and photos were taken at 24 and $72 \mathrm{~h}$ post inoculation (hpi). (B) Measurement of the diameter of infection zones at 24 and 72 hpi. Error bars represent the standard deviation and letters represent significant differences (Duncan's new multiple range test, $p<0.05$ ).

In another experiment, the N21-PS $(40 \mu \mathrm{g} / \mathrm{mL})$, carbendazim (800 times dilution, $\sim 0.88 \mathrm{mg} / \mathrm{mL}$ ) and sterile water was respectively used to spray the surface of strawberries and tomatoes. After standing the plants for $24 \mathrm{~h}$ in a lighted incubator at $25^{\circ} \mathrm{C}$, conidial suspensions $\left(5 \times 10^{5}\right.$ spores $\left./ \mathrm{mL}\right)$ or blocks of $B$. cinereal (the pathogen inducing grey mould) were inoculated on the wounded surface of strawberry and tomato plants and cultivated in a chamber at $25^{\circ} \mathrm{C}$ with $50 \%$ humidity. The results revealed that the strawberries and tomatoes treated with the N21-PS and carbendazim showed delayed occurrence time of grey mould compared to the water-treated control. The inhibition rate of $B$. cinerea by the N21-PS was $31.3 \%$ in strawberry on the fourth day after inoculation, which was smaller than the inhibition effect of carbendazim ( 54.3\%). However, opposite effects were observed in tomato, where higher inhibition rate was seen in treatments with N21-PS than with carbendazim (Table 2). All these results demonstrate that N21 peptide can delay the disease occurrence time and increase the resistance to grey mould. 
Table 2. Resistance of N21 peptide to grey mould.

\begin{tabular}{ccccc}
\hline Plants & Treatment & $\begin{array}{c}\text { Disease Time } \\
\mathbf{( d )}\end{array}$ & $\begin{array}{c}\text { Diameter of } \\
\text { Lesions }^{\mathbf{b}} \mathbf{( \mathbf { c m } )}\end{array}$ & $\begin{array}{c}\text { Inhibition Rate }^{\mathbf{c}} \\
\mathbf{( \% )}\end{array}$ \\
\hline \multirow{3}{*}{ strawberry } & N21-PS & 4 & $2.4 \pm 0.4^{*}$ & $31.4 \pm 4.1$ \\
& carbendazim & $>4$ & $1.6 \pm 0.2^{*}$ & $54.3 \pm 1.7$ \\
& water & 2 & $3.5 \pm 0.3$ & \\
tomato & N21-PS & 3 & $3.9 \pm 0.5^{*}$ & $48.6 \pm 1.6$ \\
& carbendazim & 2 & $4.5 \pm 0.3^{*}$ & $40.0 \pm 2.1$ \\
\hline
\end{tabular}

Thirty strawberry or tomato plants were disinfected with $75 \%$ alcohol, then washed with sterilized water 3 times and dried. The plants were divided into three groups: sprayed with the N21 peptide solution (N21-PS) $(40 \mu \mathrm{g} / \mathrm{mL})$, carbendazim diluted 800 times $(\sim 0.88 \mathrm{mg} / \mathrm{mL})$ or sterilized water. Plants were put in an incubator for $24 \mathrm{~h}$ with a $13 \mathrm{~h} / 11 \mathrm{~h} \mathrm{light} /$ dark at $25^{\circ} \mathrm{C}$. Conidial suspensions $\left(5 \times 10^{5}\right.$ spores $\left./ \mathrm{mL}\right)$ of $B$. cinereal were inoculated on the strawberries or hyphal blocks of $B$. cinereal were inoculated on the tomatoes on a needle-wounded surface, cultured in an incubator with a humidity of $50 \%$ at $25{ }^{\circ} \mathrm{C}$, and the disease symptoms were observed every $24 \mathrm{~h}$. a. The disease time recorded by different treatments. ${ }^{b}$. Measurement of lesion diameters on the fourth day of different treatments. ${ }^{c}$. Statistical analysis of inhibition rate compared to treatments of water. Standard deviation $( \pm \mathrm{SD})$ was calculated from three repeated experiments and asterisk indicates statistically significant differences (Duncan's new multiple range test, ${ }^{*}$ means $p<0.05$ ).

\subsection{N21 Peptide Promoted the Growth of Plants}

Previous studies demonstrated that harpins have growth-promoting effects and can increase the drought resistance in several plant species [35-37]. Therefore, we investigated whether N21 peptide had the similar effects. To test its growth-promoting effect, tomato plants grown in pots were sprayed with sterile water or N21-PS $(40 \mu \mathrm{g} / \mathrm{mL})$ every ten days, and then allowed to grow for 45 days before observation. The results showed that the tomato plants sprayed with the N21-PS reached a plant height of $\sim 49.0 \mathrm{~cm}$, fresh weight of $\sim 20.1 \mathrm{~g}$ and root length of $\sim 11.7 \mathrm{~cm}$, which represent $11.6 \%, 19.1 \%$ and $7.09 \%$ of increase, respectively, compared to the water-sprayed plants (Figure 5 and Table 3 ).

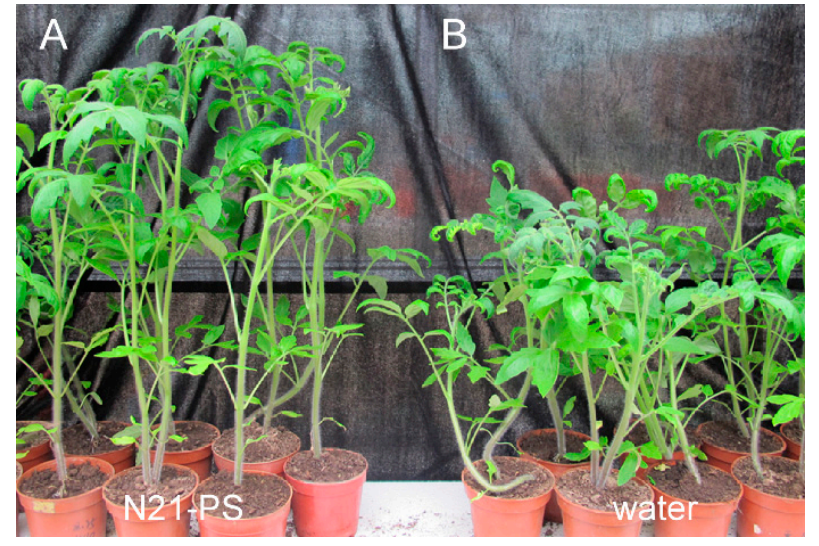

Figure 5. N21 peptide promotes the growth of tomato plants. Thirty tomato seeds were disinfected with $75 \%$ alcohol, soaked with $30 \%$ sodium hypochlorite for $30 \mathrm{~min}$ and washed with sterile water 5 times. These seeds were placed in sterile water to accelerate germination at $25^{\circ} \mathrm{C}$. After the seeds germinated, they were divided into two groups: one group was watered with a spray of the N21 peptide solution (N21-PS) $(40 \mu \mathrm{g} / \mathrm{mL}$ ) every ten days (A), the other was watered every ten days (B). The growth of tomato seedlings was observed and photographed at 45 days. 
Table 3. Promoting effect of N21 peptide on growth of tomato plants.

\begin{tabular}{cccc}
\hline Treatment & Plant Height $\mathbf{( c m )}$ & Fresh Weight $(\mathrm{g})$ & Root Length $(\mathrm{cm})$ \\
\hline N21-PS & $49.0 \pm 0.2^{*}$ & $20.1 \pm 0.3^{*}$ & $11.7 \pm 0.3^{*}$ \\
water & $43.3 \pm 0.3$ & $16.3 \pm 0.5$ & $10.9 \pm 0.1$ \\
\hline
\end{tabular}

Thirty tomato seeds were disinfected with $75 \%$ alcohol immersed for $5 \mathrm{~min}$, and dipped into $30 \%$ sodium hypochlorite solution for $30 \mathrm{~min}$, then washed with sterilized water 5 times. After seed germination, plants were placed in an incubator with the cycle of $13 \mathrm{~h} / 11 \mathrm{~h}$ light/dark at $25^{\circ} \mathrm{C}$ and sprayed with sterile water or the N21 peptide solution (N21-PS) $(40 \mu \mathrm{g} / \mathrm{mL})$ every ten days. Plant height, fresh weight and root length were measured and photographed after 45 days. Standard deviation $( \pm S D)$ was calculated from three repeated experiments and asterisk indicates statistically significant differences (Student's $t$ test, ${ }^{*}$ means $p<0.05$ ).

Then, we tested the growth-promoting effect of N21-PS in seedling of several plants. Sterilized seeds of tomato, pepper, cucumber, melon and wheat were dipped in the N21-PS $(40 \mu \mathrm{g} / \mathrm{mL})$ or sterile water and placed in an incubator at $25^{\circ} \mathrm{C}$ with a $13 \mathrm{~h}$ light $/ 11 \mathrm{~h}$ dark cycle for 5 days, and the root length was recorded. The root length of plants treated with the N21-PS were 12\% (tomato), $24.8 \%$ (pepper), $51.4 \%$ (cucumber), $11.7 \%$ (melon) and $4.9 \%$ (wheat) higher than the water-treated plants, respectively (Table 4). The germinated seedlings of different plant species were planted in pots and sprayed with sterile water or N21-PS every two days and the plant height was measured on the tenth day. The results showed that N21-PS effectively promoted the growth of the plants treated, especially pepper, whose plant height was $29.4 \%$ higher than the water-treated plants. N21-induced increase of plant height was also seen in cucumber $(20.9 \%)$, wheat $(12.4 \%)$, tomato $(12.3 \%)$ and melon $(7.0 \%)$ (Table 4). Taken together, these results provided evidence that N21 peptide could also promote plant growth.

Table 4. Promoting effect of N21 peptide to seeds of different plants.

\begin{tabular}{|c|c|c|c|c|c|c|}
\hline & Treatment & Tomato & Pepper & Cucumber & Melon & Wheat \\
\hline Root length $^{\mathrm{a}}$ & $\begin{array}{l}\text { N21-PS } \\
\text { water }\end{array}$ & $\begin{array}{c}5.73 \pm 0.25^{*} \\
5.13 \pm 0.21\end{array}$ & $\begin{array}{c}7.90 \pm 0.44^{*} \\
6.33 \pm 0.45\end{array}$ & $\begin{array}{l}4.80 \pm 0.26^{*} \\
3.17 \pm 0.23\end{array}$ & $\begin{array}{c}4.10 \pm 0.26^{*} \\
3.67 \pm 0.15\end{array}$ & $\begin{array}{c}8.60 \pm 0.62 * \\
8.20 \pm 0.30\end{array}$ \\
\hline Plant height ${ }^{b}$ & $\begin{array}{l}\text { N21-PS } \\
\text { water }\end{array}$ & $9.10 \pm 0.20 *$ & $13.37 \pm 0.45 *$ & $16.00 \pm 0.44 *$ & $9.17 \pm 0.47 *$ & $35.30 \pm 0.40$ * \\
\hline
\end{tabular}

Seeds of tomato, pepper, cucumber, melon and wheat were disinfected with $75 \%$ alcohol for 5 min, soaked with

$30 \%$ sodium hypochlorite for $30 \mathrm{~min}$, and finally rinsed with sterilized water 5 times. Seeds of each variety were divided into two groups: dipped in a N21 peptide solution (N21-PS) $(40 \mu \mathrm{g} / \mathrm{mL})$ or sterilized water at $4{ }^{\circ} \mathrm{C}$ for $3 \mathrm{~h}$ then transferred to an incubator at $25{ }^{\circ} \mathrm{C}$ with a cycle of $13 \mathrm{~h} / 11 \mathrm{~h}$ light/dark. ${ }^{\mathrm{a}}$. Root length of different plants were measured after 5 days. Standard deviation $( \pm S D)$ was calculated from three repeated experiments and asterisk indicates statistically significant differences (Student's $t$ test, ${ }^{*}$ means $p<0.05$ ). ${ }^{b}$. Plant height of different plants transplanted into the basins were measured after 10 days. \pm SD was calculated from three repeated experiments and asterisk indicates statistically significant differences (Student's $t$ test, ${ }^{*}$ means $p<0.05$ ).

\subsection{N21 Peptide Improved the Drought Tolerance of Tobacco}

Polyethylene glycol 6000 (PEG6000) is usually used to test plants' drought responses $[36,38,39]$. We used 10\% PEG6000 to simulate drought stress in tobacco. 60-day-old tobacco seedlings were irrigated with 10\% PEG6000 for $48 \mathrm{~h}$ and the leaves were sprayed with water, N21-PS ( $80 \mu \mathrm{g} / \mathrm{mL})$ or the same amount of Hpa1 protein expressed from E. coli every day. The results showed that the plants treated with the N21-PS only exhibited mild wilting, and the leaves returned to normal after re-watering. However, tobacco plants sprayed with sterile water showed irrecoverable leaf wilting and signs of yellowing. Plants treated with the same amount of Hpa1 protein showed clear wilting symptoms, but milder than those treated with sterile water (Figure 6A). Consistently, the relative water content (Figure 6B), germination rate (Figure S4A,B) and survival rate (Figure $\mathrm{S} 4 \mathrm{C}, \mathrm{D}$ ) of the plants, showed similar change patterns. A significantly higher expression of the drought-stress genes (NtERD10B and NtLEA5), genes for ROS detoxification (NtSOD, NtAPX and NtCAT) and signaling components (NtPLC3 and NtCMK1) was observed in the plants treated with the N21-PS and Hpa1 proteins, relative to the water-treated 
plants, with highest expression in the N21-PS treatment (Figure 6C-I). All these results indicated that the $\mathrm{N} 21$ peptide could improve the drought tolerance of tobacco plants even better than the full-length Hpa1 protein.

A
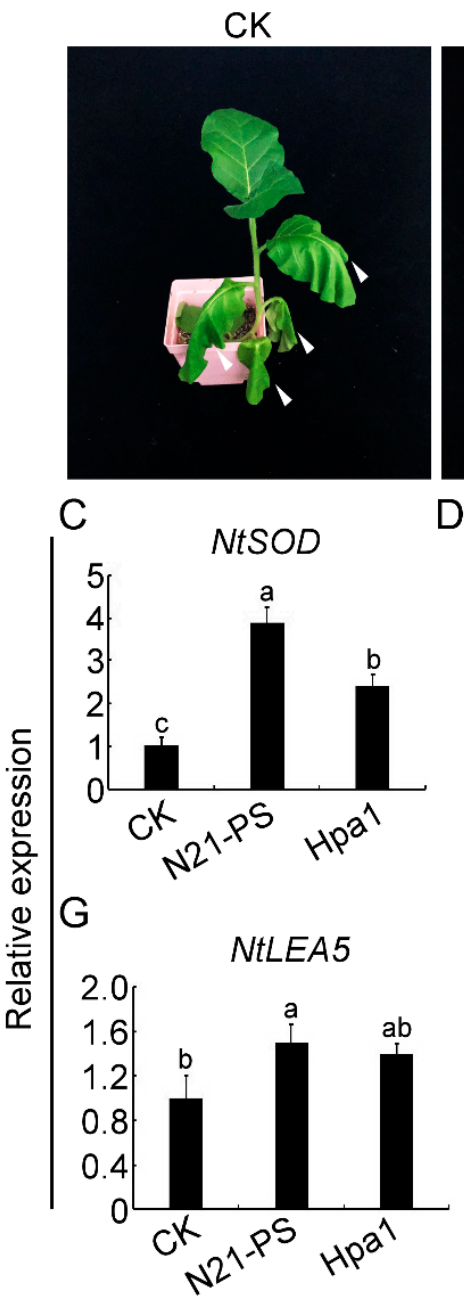

N21-PS

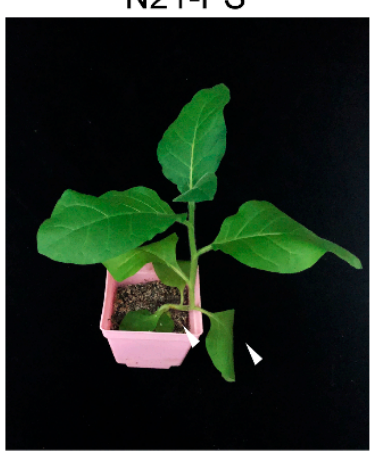

D

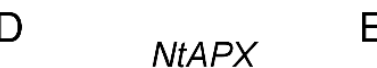

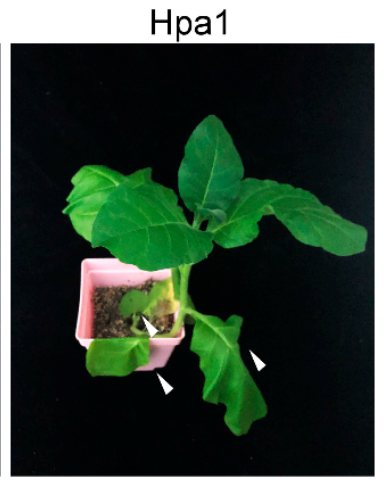

E

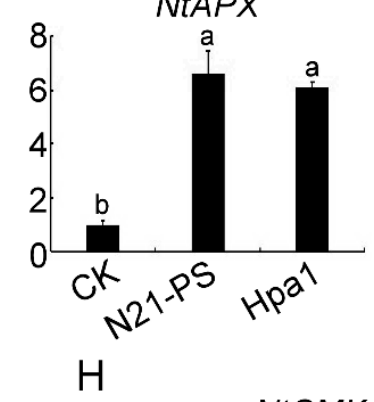

NtCMK1

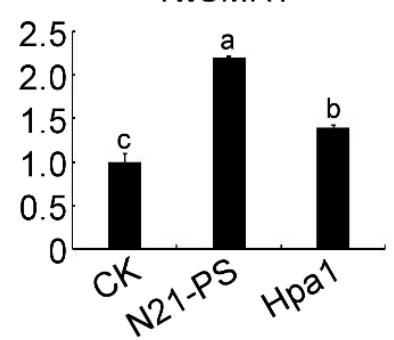

B

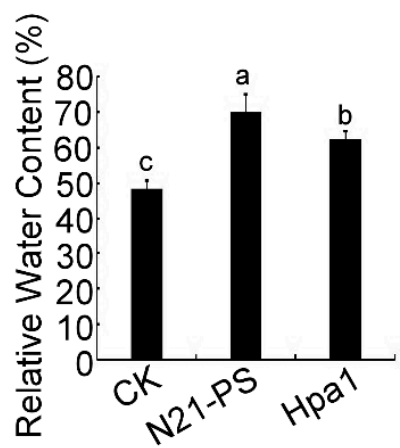

$\mathrm{F}$

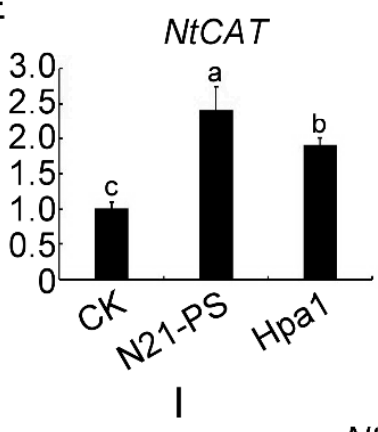

NtPLC3
NtERD10B

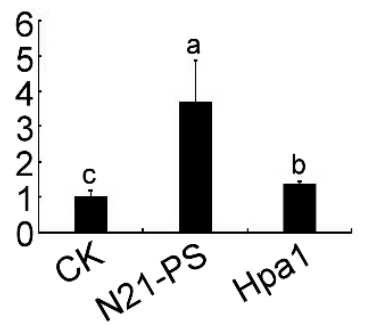

Figure 6. N21 peptide improves the drought tolerance of tobacco plants. (A) Drought stress of tobacco was treated with a 10\% polyethylene glycol 6000 (PEG6000) solution. Nine Xanthi tobacco plants were divided into three treatment groups. The roots of plants were irrigated with 10\% PEG6000 for $48 \mathrm{~h}$, and sprayed on the surface with sterile water (the left plant), $80 \mu \mathrm{g} / \mathrm{mL}$ N21 peptide solution (N21-PS) (the middle plant) and the same amount of Hpa1 expressed in Escherichia coli (E. coli) (the right plant) every day. Photos were taken at 48 hpi. The white arrow indicated the arid area. (B) Different treatment effects were observed by estimating relative water content (\%). Error bars represent the standard deviation and letters represent significant difference (Duncan's new multiple range test, $p<0.05$ ). The relative expression of stress-responsive genes of (C) NtSOD; (D) NtAPX; (E) NtCAT; (F) NtERD10B; (G) NtLEA5; (H) NtCMK1; (I) NtPLC3 was measured by qRT-PCR under different treatments. Error bars represent the standard deviation and letters represent significant differences (Duncan's new multiple range test, $p<0.05$ ).

\subsection{Coiled-Coil N21 Upregulated the Expression of Multiple Defence Response Genes in Tobacco}

To further examine the molecular mechanisms of the induced resistance of coiled-coil N21, we measured the transcription of 11 defense-related genes in N21-expressing, Hpa1-expressing and EV tobacco plants, including four salicylic acid (SA)-related genes (PR-1a, PR-1b, PR2, NPR1), two jasmonic acid (JA) synthesis genes (LOX1, AOC4), three ethylene (ET) synthesis and signaling genes (ACS1, ACS2, EIN2), and two reactive oxygen species (ROS) synthesis-related genes $(R B O H A, R B O H B)$. The results showed that nearly all 
the tested genes had higher expression in trans-Hpa1 tobacco compared to the trans-N21 and EV tobacco plants. The PR-1a, PR-1b, PR2, NPR1, LOX1, AOC4, ACS2, RBOHA and $R B O H B$ genes were upregulated in N21-expressing and Hpa1-expressing tobacco plants as compared with the EV tobacco plants (Figure 7A-D). However, the expression of some genes was significantly different between the trans-N21 and trans-Hpa1 plants. Among these, the expression of $P R-1 a$ in N21-expressing plants were $~ 30$-fold higher than in Hpa1-expressing tobacco plants (Figure 7A). The expression of $P R-1 b, P R 2$, LOX1, and RBOHA was dramatically higher in trans-Hpa1 tobacco than in trans-N21 tobacco (Figure 7A,B,D). These results indicated that the coiled-coil N21 could induce an immune response in transgenic tobacco and play a similar role as $\mathrm{Hpa}_{\mathrm{X}_{\mathrm{Oo}}}$ in some of the defense responses, however, it also plays some different roles in defense as reflected by its different effects on gene expression.
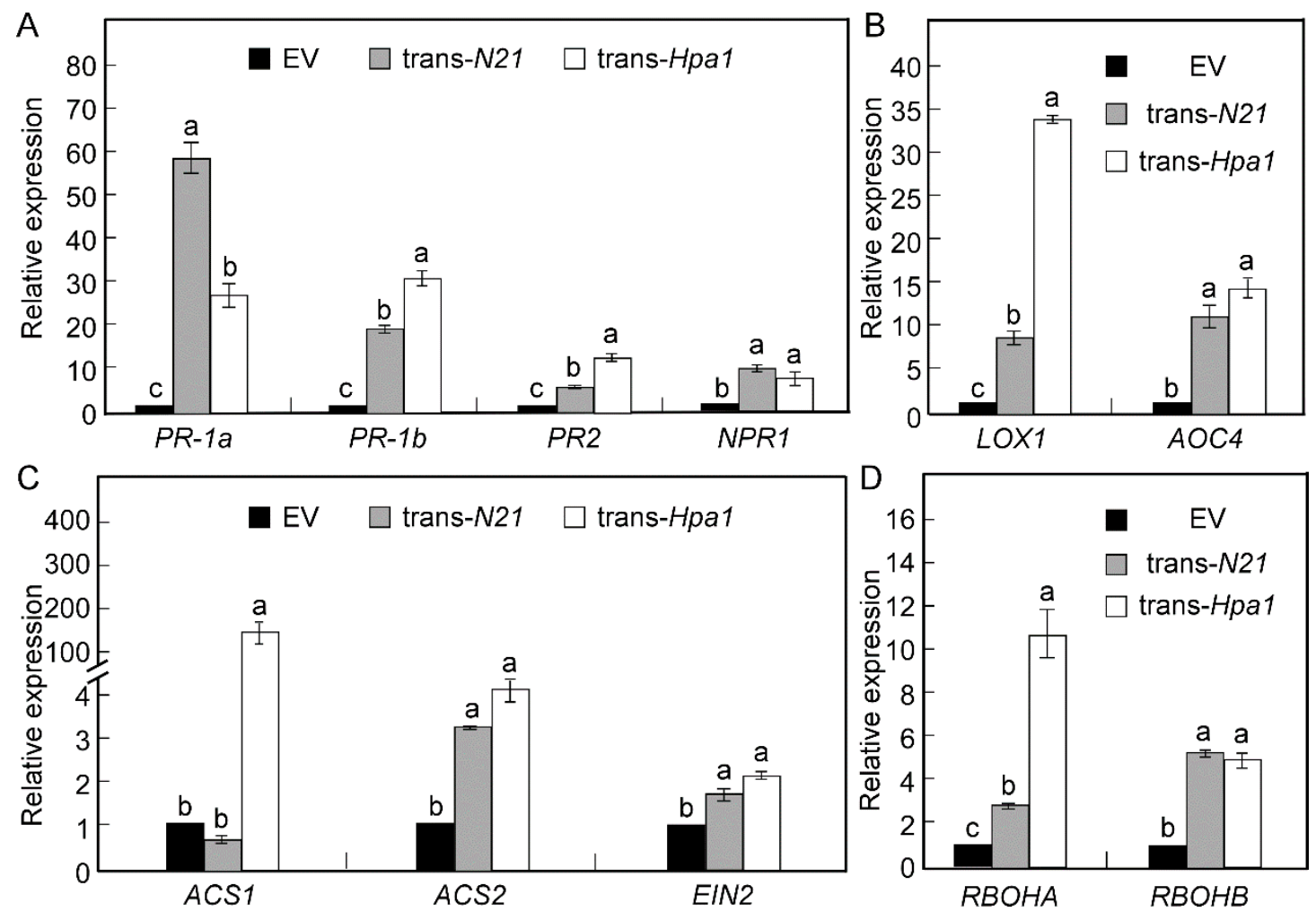

Figure 7. Expression analysis of plant defense-related genes in different transgenic tobacco. Total RNA was separately extracted from fully unfolded leaves in 6-week tobacco strains expressing pBI121 vector (EV), trans-N21 and trans-Hpa1. cDNA was reversed transcribed. (A-D) The relative expression of four salicylic acid (SA) signaling-related genes (PR-1a, $P R-1 b, P R 2, N P R 1)(A)$, two jasmonic acid (JA) biosynthesis genes (LOX1, AOC4) (B), three ethylene (ET) synthesis and signaling genes ( $A C S 1, A C S 2, E I N 2)(C)$, and two reactive oxygen species (ROS) synthesis-related genes $(R B O H A, R B O H B)$ (D). $E F-1 \alpha$ was used as a reference gene. Standard deviation $( \pm \mathrm{SD})$ was calculated from three repeated experiments, and lowercase letters indicate statistically significant differences (Duncan's new multiple range test, letters mean $p<0.05$ ).

\subsection{N21 Peptide Has Better Bioavailability than Hpa1 Xoo}

The above results suggest that the N21 peptide has similar effects than the full-length Hpa1, including promoting plant growth, inducing HR in non-host, increasing disease and drought tolerance. The N21 effect in inducing drought tolerance was even better than the full-length Hpa1. Interestingly, the trans- $N 21$ tobacco also had lower -virus or bacterial content than that in trans-Hpa1 tobacco in the early stage of infection, and showed similar resistance to trans-Hpa1 in the late stage of infection (Figures $2 \mathrm{~B}$ and $3 \mathrm{~B}$ ), suggesting that trans-N21 had better anti-microbial effect in the early stage of pathogen invasion. Considering the limitation of biopesticide Messenger or Illite in production, and the advantage of the N21 short peptide, we wondered whether N21 peptide could be 
more easily absorbed by the host plant and used as a succedaneum of Hpa1. To test this possibility, disinfected tomatoes were sprayed on the surface with the N21 peptide solution of $40 \mu \mathrm{g} / \mathrm{mL}$, equal amount of Hpa1 protein expressed from E. coli and sterile water, left for $24 \mathrm{~h}$ under suitable conditions. Then the wounds were inoculated with hyphal blocks of $B$. cinerea and then blocks were removed at $24 \mathrm{hpi}$. The results showed that tomatoes treated with N21-PS presented the smallest lesions, only about $1.9 \mathrm{~mm}$, compared to the non-treated tomatoes at $48 \mathrm{~h}$ of inoculation. However, diameters of infection zones of tomatoes treated with water was $\sim 15.5 \mathrm{~mm}$ and a distinct layer of mildew developed in the diseased area. Tomatoes treated with same amount of $\mathrm{Hpa} 1$ protein exhibited distinctly depressed diseased area, but bigger than that in N21-PS-treated plants, about $6.9 \mathrm{~mm}$ (Figure $8 \mathrm{~A}, \mathrm{~B}$ ). Since the hyphal blocks were removed at $24 \mathrm{~h}$, the onset of the disease was slower. At $96 \mathrm{~h}$ after inoculation, visible disease area within a small amount of mildew was observed in tomatoes treated with N21-PS. At the same time, tomatoes treated with water or Hpa1 protein all exhibited marked disease symptoms with more mildews, but there were still significant differences between three treatments (Figure 8A,B). All these results indicate that exogenous spray of N21 peptides exhibited a better bioavailability than that of the full-length Hpa1, and thus has higher disease resistance effect.

A

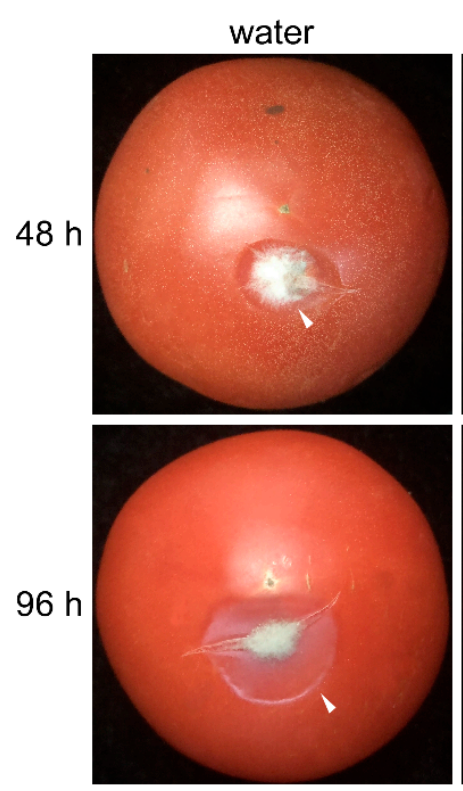

N21-PS
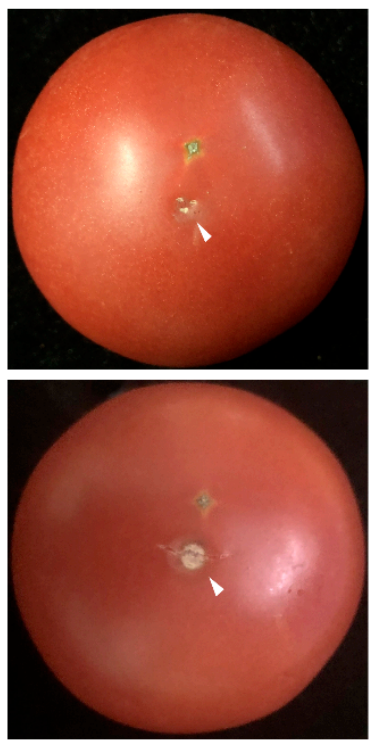

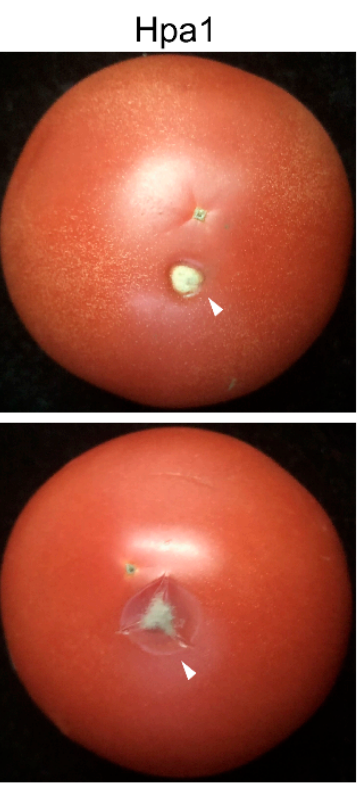

B

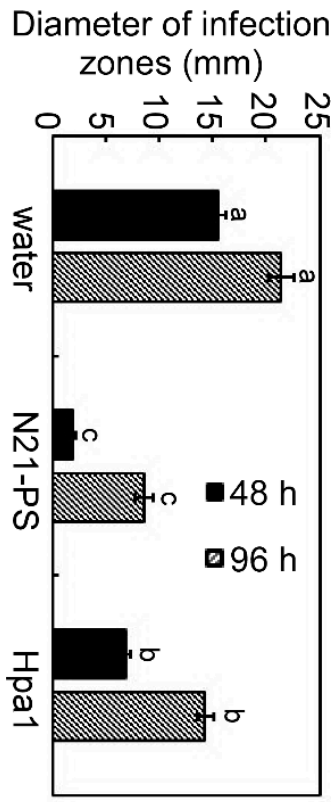

Figure 8. The N21 peptides of Xanthomonas oryzae pv. oryzae showed a better plant bioavailability than that of the full-length Hpa1 protein. (A) Tomatoes were disinfected with $75 \%$ alcohol, washed with sterile water 3 times and dried. Then plants were treated with $3 \mathrm{~mL}$ of $40 \mu \mathrm{g} / \mathrm{mL}$ N21-PS, the same amount of Hpa1 protein expressed from E. coli or sterile water, separately, in an incubator with a $12 \mathrm{~h} / 12 \mathrm{~h}$ light/dark cycle for $24 \mathrm{~h}$. Then hyphal blocks of $B$. cinera were inoculated on the wounds and put them in an incubator with 50\% relative humidity $(\mathrm{RH})$. The incidence was recorded and photographed every $48 \mathrm{~h}$. White arrows indicate the area of the disease. N21-PS represents N21 peptide solution. E. coli stands for Escherichia coli. (B) Diameter of infection zones was measured at 48 or $96 \mathrm{~h}$ post inoculation (hpi). Standard deviation ( \pm SD) was calculated from three repeated experiments, and lowercase letters indicate statistically significant differences (Duncan's new multiple range test, letters mean $p<0.05)$. hpi represents hours post inoculation.

Apart from tomato, N21-PS or the same amount of Hpa1 protein expressed in E. coli were sprayed on the rice leaves before inoculating with the suspension of PXO99 of Xoo, separately. Rice leaves inoculated only with the suspension of PXO99 were treated as the positive control, and rice leaves treated with sterile water surface spray as the negative control. Then the plants were cultured in a constant temperature incubator at $25^{\circ} \mathrm{C}$ with a RH of $80 \%$ after inoculation, and the incidence was recorded. The results showed that 
the symptoms of rice leaves going yellowing and dying were rather small, only had a lesion diameter of $\sim 4.5 \mathrm{~mm}$, when pretreated with N21 peptide solution, whereas the leaves pretreated with Hpa1 protein exhibited larger yellowing lesions, about $15.9 \mathrm{~mm}$ in lesion diameter. At the same time, the leaves treated only with suspension of PXO99 had the most severe disease symptoms, the diameter of lesions was $\sim 51.8 \mathrm{~mm}$ (Figure S5A,B). Measurement of relative content of Xoo also showed consistent results, which were significantly different among the three treatments (Figure S5C). All these results indicated that both N21 and Hpa1 could increase the resistance of rice to Xoo and the N21 peptide had much better bioavailability than the full-length Hpa1 protein.

\section{Discussion}

We showed in this study that the most stable and shortest coiled-coil regions formed by 21 amino acid residues ( 3 heptads) encoding $\mathrm{N}^{2} 1_{\mathrm{Hpa} 1}$ could induce HR in non-host tobacco using both proteins purified from E. coli and trans-N21 tobacco. Trans-N21 effectively enhanced resistance of tobacco to TMV and Pcc. The spraying of a N21 peptide solution effectively reduced the brown rot disease of peach, and this antifungal effect was much better than fungicides such as procymidone. Further, the N21 peptide delayed the occurrence of disease, reduced the disease severity, and improved the resistance of strawberries and tomatoes to $B$. cinerea. We also found that exogenous spray of N21 peptide promoted the growth of roots and increased of plant height in wheat, pepper, tomato and other plants, and induced drought tolerance in tobacco even more effective than Hpa $1_{X_{o o}}$. These effects are consistent with previous studies for the effects of harpin proteins in promotion of plant growth, development, disease resistance and other beneficial phenotypes $[1,2,6,7,36,40,41]$. These results suggested that N21 enabled plants to obtain beneficial phenotypes, such as disease resistance, increased growth and drought tolerance, in vivo and in vitro. Our results indicated that coiled-coil N21 is an important functional unit of Hpa1 Xoo $_{\text {. }}$.

Plants have a sophisticated immune system to respond to pathogens or microorganisms, including PAMP-triggered immunity (PTI) and effector-triggered immunity (ETI). These systems recognize the pathogens using immune receptors, which activate downstream defense responses, such as oxidative bursts, hypersensitive reactions, and the activation of MAPK and $\mathrm{Ca}^{2+}$ signaling [42-45]. To further understand the molecular mechanisms of induced resistance by N21 and full-length Hpa1 $\mathrm{Xoo}_{\mathrm{oo}}$, we examined the expression of a series of defense response genes. Notably, the defense-related genes $P R-1 a$, $P R-1 b$ and $P R 2$, especially $P R-1 a$, were highly upregulated, which may underlie the disease resistance induced by coiled-coil N21. These genes are SA signaling-related genes, and phytohormones including JA, SA and ET are well known to be involved in plant defense responses [46-48]. SA plays pivotal roles in biotrophic pathogens to activate plant defense, and ET and JA primarily function in necrotrophic pathogens [42,49].

We also found that the ET synthesis-related gene ACS2, the JA synthetic genes LOX1 and AOC4, and the SA-regulated genes PR-1a, PR-1b, PR2 and NPR1 showed higher expression in N21-expressing and Hpa1-expressing tobacco plants than that of in EV plants, which indicate that the overexpression of $\mathrm{N} 21$ or $\mathrm{Hpa}_{\mathrm{X}_{\mathrm{oo}}}$ in plants might activate hormonecontrolled signaling pathways to induce resistance mechanisms, such as growth promotion, disease and drought tolerance. Our results showed that the heights of trans- $N 21$ and transHpa1 tobacco plants were much higher than that of EV tobacco, and exogenous application of the N21 peptide solution enhanced the ability of drought tolerance of tobacco plants. Promotion of plant growth and stress resistance by harpins in vitro and in vivo have been reported previously in other plant species. For instance, overexpression of harpin genes or spray of a harpin solution was found to be able to promote plant growth via regulation of the ET-mediated signaling pathway [8,35]. Niu et al. (2019) have demonstrated that introduction of harpin Xoc $_{\text {-encoding gene }} h r f 2$ in soybean could enhance the resistance of Phytophthora sojae via the upregulation of SA- and JA-dependent genes [50]. These studies, together with our results, suggest that SA and JA work synergistically to induce biotic or abiotic stress resistance in host plants. 
The respiration burst oxidase genes $R B O H A$ and $R B O H B$ were upregulated in trans$\mathrm{N} 21$ and trans-Hpa1 tobacco plants, which indicate that the ROS production in transgenic plants might have been increased to activate the expression of disease-resistant genes, such as $P R-1 a, P R-1 b$ and $P R 2$, and thus inhibiting the invasion of pathogens and increasing plant's disease resistance. The expression levels of $P R-1 a, P R-1 b, P R 2, L O X 1, A C S 1$ and $R B H O A$ genes were notably different between trans-N21 and trans-Hpa1 plants, indicating that, although the overexpression of N21 in plants or the exogenous addition of N21 peptide produced similar phenotypes to full-length $\mathrm{Hpa}_{\mathrm{X}_{\mathrm{oo}}}$ in disease resistance, drought tolerance and growth promotion, trans- $\mathrm{N} 21$ and trans-Hpa1 have different functions in defense responses. N21 is just a small part of the Hpa1 protein (full length consists of $139 \mathrm{aa}$ ), and our previous work demonstrated an opposite function of the coiled-coil CC domain in the N-terminal and C-terminal of Hpal Xoo $_{\text {[12]. In addition, Dong et al. has }}$ demonstrated both the $\mathrm{N}$-terminal and C-terminal $\alpha$-helices of Hpa1 ${ }_{\mathrm{Xoo}}$ mutation could induce reduction of the pathogenicity of Xanthomonas oryzae pv. oryzae [9], indicating that the 21 aa of C-terminal Hpa1 Xoo $_{\text {oo }}$ also play an important role in the pathogenesis of disease or other sides of pathogen. These might be the reasons for the differential expression of the defense-related genes in trans-N21 and full-length transgenic tobacco.

In the present study, we demonstrated that the coiled-coil structure N21 in the Nterminal had similar function with Hpa1, with even stronger effect in inducing drought tolerance. Besides, we were surprised that the relative content of virus or bacteria in trans-N21 tobacco were significantly lower than that in the trans-Hpa1 plants in early stage of infection, and which tended to be similar in the later stage of infection. Furthermore, results of this study indicated that N21 peptide was more easily absorbed by plants than the full-length Hpa1 protein, and exhibited a better bioavailability, which supports the broad application prospects of this peptide as a promising succedaneum to Messenger or Illite or other biological pharmaceutical products, and it is possible to integrate with other products, such as engineered bacteria.

In summary, in this study we examined the biological function of the most stable and shortest three heptads $\mathrm{N} 21$ of $\mathrm{Hpa} 1_{\mathrm{XoO}_{\mathrm{oO}}}$ in vivo and in vitro. The trans-N21 tobacco plant exhibited improved resistance to TMV and $P c c$, which was consistent with the results from trans-Hpa1 tobacco. Treatment with a N21 peptide solution delayed the time of disease occurrence of $M$. fructicola and B. cinerea, promoted plant growth and drought tolerance in tobacco plants. N21 induced the expression of multiple plant defense-related genes, and had better bioavailability than the full-length Hpa1 protein. Our studies provide a basis for further development and use of proteins with similar structures.

\section{Materials and Methods}

\subsection{Plant Materials, Pathogenic Strains, Pesticides and Growth Conditions}

Nicotiana tabacum L. "Xanthi", trans-Hpa1 tobacco, EV tobacco, TMV, Pcc, B. cinereal, PXO99 and M. fructicola were maintained in the laboratory. Tobacco strains of expressing$H p a 1_{X o o}$ and empty vector, and E. coli strains expressing N21 in were obtained from Nanjing Agriculture University [12,13,32,51]. Trans-N21 tobacco was obtained using the leaf-disc method after at least three generations of sub-culture. $35 \mathrm{~S}$ promoter of Cauliflower mosaic virus (CaMV)_was used to drive the expression of N21 and Hpa1 in the transgenic tobacco. The N21 peptide was synthesized using the F-moc solid-phase peptide synthesis method (Nanjing Kingsrui company, China). Synthetic peptides were packaged in tubes of $4 \mathrm{mg}$ each and stored as freeze-dried powder at $-80^{\circ} \mathrm{C}$.

Strawberries ("Fengxiang") and tomatoes ("Jinguan" no. 5) came from experimental and demonstration bases of Jiangwang in Yangzhou, Jiangsu, China. Peach plants ("Hujingmilu") were from peach experimental and demonstration bases at Yangshan, Wuxi, China. Seeds, such as pepper ("Huayu" 8819), melon ("Yangyan"), cucumber ("Jinyang" of new no. 4), wheat ("Ningmai"13), tomato ("Dehua"), procymidone (Sumitomo Chemical Industry Corporation of Japan, 50\% wettable powder, Shanghai, China) and carbendazim 
(Taicang Agricultural Pharmaceutical Factory Co. LTD of China, 70\% wettable powder, Suzhou, China) were purchased from agricultural stores in China.

Nicotiana tabacum L. "Xanthi", trans-N21 tobacco, trans-Hpa1 tobacco and EV tobacco plants were potted in a greenhouse at $25^{\circ} \mathrm{C}$ with $80 \%$ humidity for $7-8$ weeks (approximately 6-7 leaf stage).

\subsection{Acquisition of N21-Transgenic Tobacco}

The expression vector was transformed into EHA105 of Agrobacterium tumefaciens using a freeze-thaw method to obtain recombinant strains. The antibiotic-resistant single colony was cultured in YEB media with $50 \mu \mathrm{g} / \mathrm{mL}$ of kanamycin $(\mathrm{km}$ ) (Diamond, A1004080005, Sangon Biotech, Shanghai, China) and $25 \mu \mathrm{g} / \mathrm{mL}$ of chloramphenicol $(\mathrm{Cm}$ ) (Diamond, A100230-0010, Sangon Biotech, China) to the logarithmic phase, centrifuged at $4000 \mathrm{r} / \mathrm{min}$ for $10 \mathrm{~min}$, washed and resuspended in $20 \mathrm{~mL}$ Murashige \& Skoog medium (MS) through standard procedure. The selected leaves of tobacco seedlings were completely spread out and disinfected, and the leaf plates were taken with a sterilizing perforator. The leaf disc was placed into the bacterial suspension using sterile forceps and vortexed $30 \mathrm{~s}$ to ensure that the transforming bacterial solution fully contacted the wound site of the leaf tissue. The discs were placed on sterile filter paper to allow the excess bacteria on the surface to dry, and placed on an MS co-culture medium (MS + $1 \mathrm{mg} / \mathrm{L}$ 6-BA) for 3-4 days in the dark at $25^{\circ} \mathrm{C}$. The transformed leaf discs were transferred to the differentiated media (MS + $100 \mathrm{mg} / \mathrm{L} \mathrm{km}+500 \mathrm{mg} / \mathrm{L}$ Carbenicillin $(\mathrm{Cb})+1 \mathrm{mg} / \mathrm{L}$ 6-BA) for $5-7$ weeks at $25^{\circ} \mathrm{C}$ with a relative humidity $(\mathrm{RH})$ of $66 \%$. When the buds grew to greater than $2 \sim 3 \mathrm{~cm}$, the buds were cut and transferred to the rooting medium $(1 / 2 \mathrm{MS}+100 \mathrm{mg} / \mathrm{L} \mathrm{km}+0.2 \mathrm{mg} / \mathrm{L}$ IAA) The roots were grown for $2-3$ weeks, and the seedlings were transplanted into a pot and cultured in a greenhouse $\left(25^{\circ} \mathrm{C}, 80 \% \mathrm{RH}\right)$. gDNA of transgenic tobacco was extracted using the AxyPrep Multisource Genomic DNA Miniprep Kit (Axygen, Tewksbury, MA, USA). RNA was extracted using the PureLink ${ }^{\mathrm{TM}}$ RNA Mini Kit (Invitrogen, Cat no. 12183018A, Nanjing, China). PCR and semi-quantitative RT-PCR detection, and sequencing were performed to verify the correctness of the target gene (N21) inserted into the transgenic tobacco. Transgenic seeds were propagated continuously to T3 generations by $\mathrm{km}$ selection, PCR and semi-quantitative RT-PCR. The primers used are listed in Table S1.

\subsection{Protein Activity Assay in Trans-N21 Tobacco Plants}

Forty-five-day fresh leaves of trans- $N 21$ tobacco were cut and immediately ground into a powder using liquid nitrogen. The samples were placed into $1 \mathrm{~mL}$ of plant protein extraction buffer (50 mM Tris- $\mathrm{HCl}$ ( $\mathrm{pH} 7.0), 10 \mathrm{mM} \mathrm{MgCl} 2,1 \mathrm{mM}$ EDTA, $5 \mathrm{mM}$ DTT, 5\% PVP, $10 \%$ glycerine) and $10 \mu \mathrm{L}$ PMSF $(100 \mathrm{mM})$, shocked for $10 \mathrm{~min}$, and incubated for $3 \mathrm{~h}$ at $4{ }^{\circ} \mathrm{C}$. The samples were centrifuged at $12,000 \mathrm{r} / \mathrm{min}$ for $20 \mathrm{~min}$ at $4{ }^{\circ} \mathrm{C}$, and the supernatant was taken. The supernatant was dried then dissolved in $500 \mu \mathrm{L}$ sterile water, and measured protein concentration via Bradford protein concentration assay kit (Beyotime, P0006) for the detection of protein activity. A small hole was created in the lower epidermis of a fully expanded leaf of Xanthi tobacco, and the prepared protein solution was injected into the hole using a 1-mL needle. The plants were cultured in a $16 \mathrm{~h} / 8 \mathrm{~h}$ light/dark cycle at $25^{\circ} \mathrm{C}$ for $24 \mathrm{~h}$ to observe the results. Proteins of EV tobacco and Xanthi tobacco were extracted as negative controls. Proteins of N21 and Hpa1 directly expressed by E. coli BL21 cells were used as positive controls. The experiment was repeated three times with the same results.

\subsection{Determination of Resistance of Trans-N21 Tobacco to TMV and Pcc}

TMV was inoculated via friction inoculation. A small amount of quartz sand (400 mesh) was scattered on the leaves. A TMV suspension $(10 \mu \mathrm{L})$ was evenly dripped onto the leaves of trans-N21 tobacco, and inoculated via gently rubbing the leaves with fingers. After inoculation, the leaves were gently rinsed with water, and the experimental plants were cultured in an isolated greenhouse at $25^{\circ} \mathrm{C}$ for $36-72 \mathrm{~h}$. EV and trans-Hpa1 tobacco were used as controls in each treatment. Ten plants were inoculated in each transgenic strain 
and three leaves of the same leaf age were inoculated in the middle of each plant. The experiment was repeated three times.

Fully unfolded leaves of trans-N21 plants were dipped in the suspension of Pcc at a concentration of $1.0 \times 10^{7} \mathrm{CFU} / \mathrm{mL}$ and cultured at $25^{\circ} \mathrm{C}$ for $12-16 \mathrm{~h}$. Resistance was analyzed with reference to Ger et al. [34]. EV and trans-Hpa1 tobacco were used as controls. The experiment was repeated three times, and each experiment had three replicates.

\subsection{Determination of Resistance of N21 Peptide to M. Fructicola and B. cinerea}

Peach surfaces were disinfected with $75 \%$ alcohol, cleaned with sterile water three times, and dried in a cool place. The peaches were treated with a surface spray of sterile water, an N21-PS $(40 \mu \mathrm{g} / \mathrm{mL})$ and 1000 times diluted procymidone. The treated plants were placed in an illumination incubator for $13 \mathrm{~h}$ at $25{ }^{\circ} \mathrm{C}$ with a relative humidity of $50 \%$ for $24 \mathrm{~h}$. Inoculated blocks of M. fructicola on treated peaches with needle wound at $25^{\circ} \mathrm{C}$ for 3 days. The experiment was repeated three times, and each experiment had three replicates.

Strawberries and tomatoes were disinfected as described above, and treated separately with sprays of sterile water, the N21-PS $(40 \mu \mathrm{g} / \mathrm{mL})$ and carbendazim diluted 800 times. Conidial suspensions $\left(5 \times 10^{5}\right.$ spores $\left./ \mathrm{mL}\right)$ or blocks of $B$. cinereal were inoculated on the wounded surface of strawberry and tomato plants after different treatments for $24 \mathrm{~h}$, and the disease symptoms were observed daily. The experiments were repeated with three independent materials in three replicates.

\subsection{Determination of Growth-Promoting Effect of N21 Peptide}

For the growth promotion of tomato plants, 30 tomato seeds were disinfected with $75 \%$ alcohol for $5 \mathrm{~min}$, dipped in $30 \%$ sodium hypochlorite for $30 \mathrm{~min}$ and cleaned with sterile water 5 times. After germination, planted the seeds in the pots at $25^{\circ} \mathrm{C}$ in an incubator with a $13 \mathrm{~h} / 11 \mathrm{~h}$ light/dark cycle and divided into two groups: normal watering or sprayed with a N21-PS ( $40 \mu \mathrm{g} / \mathrm{mL})$ for $5 \mathrm{~mL}$ every 10 days. After 45 days, the length of roots, fresh weight and plant height were measured.

For the growth promotion of seeds of different plants, including tomato, pepper, cucumber, melon and wheat, the same disinfection was performed for the seeds. The seeds were separately dipped into an N21-PS $(40 \mu \mathrm{g} / \mathrm{mL})$ or water at $4{ }^{\circ} \mathrm{C}$ for $3 \mathrm{~h}$ then transferred to the incubator with 13 -h light at $25^{\circ} \mathrm{C}$ for 5 days. The root length was recorded. Finally, the seeds were transplanted to pots and treated with the N21 solution or water. Plant height was recorded on the tenth day.

\subsection{Determination of Drought Tolerance Induced by N21 Peptide}

The roots of 6-week-old Xanthi tobacco were watered with a 10\% PEG6000 solution daily (treated 2 days), and the plant surface was sprayed with a solution of $80 \mu \mathrm{g} / \mathrm{mL}$ N21-PS, the same amount of Hpa1 protein or sterile water. Survival rate was measured with the seedling of 7-day-old Xanthi tobacco under the same treatment. Hpa1 protein was expressed from E. coli and the protein concentration was measured using the standard Bradford Protein Assay Kit (Beyotime P0006). Pictures were taken every 6 h. For germination rate assay, seeds of different transgenic lines were germinated on MS media containing $200 \mathrm{mM}$ mannitol [52]. Seeds germinated on MS media were used as controls. Germination rate were calculated after 21 days. Measurement of relative water content was according to Sharma et al. [52]. The leaves showed dehydration symptoms after another $48 \mathrm{~h}$ treatment was cut for drought-related gene expression analysis. The experiments were repeated three times, and each experiment had three replicates.

\subsection{Bioactivity Assay of Hpa1 and the N21 Peptide}

Tomatoes were surface-disinfected with $75 \%$ alcohol, washed with sterile water 3 times, and dried at a cool place. The tomatoes were then divided into three groups, and each group with 3 tomatoes. One group was treated with $3 \mathrm{~mL}$ of $40 \mu \mathrm{g} / \mathrm{mL}$ N21-PS; the second 
group was treated with the same amount of the Hpa1 protein expressed from E. coli; the third group treated with $3 \mathrm{~mL}$ of sterile water as the negative control. Then, the tomatoes were placed in a $12 \mathrm{~h} / 12 \mathrm{~h}$ light/dark cycle incubator at $25^{\circ} \mathrm{C}$ for $24 \mathrm{~h}$. Tomatoes were taken out, made wounds and inoculated with hyphal blocks of B. cinera. After inoculation, they were cultured in an incubator at $25^{\circ} \mathrm{C}$ with the relative humidity of $50 \%$, and incidence recorded and photographed every $48 \mathrm{~h}$. The experiments were repeated three times, and each experiment with three replicates.

\subsection{Quantitative Real-Time PCR Assays}

To analyze the expression of genes associated with the plant defense response in different transgenic tobacco strains, total RNA was extracted using the PureLink ${ }^{\mathrm{TM}}$ RNA Mini kit (Invitrogen, Cat no. 12183018A, USA). Bio-Rad was used for qRT-PCR analysis. The EF-1 $\alpha$ gene was used as the internal control. The experiment was repeated three times, and each experiment included three replicates. The primers used in this paper are shown in Table S1.

Supplementary Materials: Supplementary materials can be found at https://www.mdpi.com/1422 $-0067 / 22 / 1 / 203 /$ s1.

Author Contributions: Z.-L.J., L.-N.Y. and J.-X.H. conceived the research; M.-H.Y., Y.-Y.D. and J.L. conducted the experiments; L.-N.Y. wrote the manuscript; Z.-L.J., F.Z. and J.-X.H. revised and approved the manuscript. All authors have read and agreed to the published version of the manuscript.

Funding: This research was supported by the National Natural Science Foundation of China (Grant No. 31101475), the Yangzhou University Research Foundation for Advanced Talents (Grant No. 5018/137010407 and Grant No. 5018/137011834), the earmarked fund for Modern Agro-industry Technology Research System (Grant No. CARS-30-3-02) and Natural Science Foundation of Jiangsu Province of China (BK20201431 and BK20200929). JX He is supported by the GRF grant (Ref. No.14148916) and AoE grants (AoE/M-05/12, AoE/M-403/16) from the Research Grant Council (RGC) of Hong Kong, a grant from the National Natural Science Foundation (NSFC)-RGC Joint Scheme (N_CUHK452/17), and the Direct Grants from The Chinese University of Hong Kong.

Institutional Review Board Statement: Not applicable.

Informed Consent Statement: Not applicable.

Data Availability Statement: All the data is actually available.

Conflicts of Interest: None of the authors had a conflict of interest.

$\begin{array}{ll}\text { Abbreviations } & \\ \text { HR } & \text { hypersensitive response } \\ \text { TMV } & \text { tobacco mosaic virus } \\ \text { Pcc } & \text { Pectobacterium carotovora subsp. carotovora } \\ \text { SA } & \text { salicylic acid } \\ \text { E. coli } & \text { Escherichia coli } \\ \text { JA } & \text { jasmonic acid } \\ \text { ET } & \text { ethylene } \\ \text { ROS } & \text { reactive oxygen species } \\ \text { TAL } & \text { transcription activator-like } \\ \text { KIH } & \text { knobs-into-holes } \\ \text { CC } & \text { coiled-coil } \\ \text { EV } & \text { tobacco strains expressing pBI121 vector } \\ \text { CaMV } & \text { Cauliflower mosaic virus } \\ \text { Km } & \text { kanamycin } \\ \text { N21-PS } & \text { N21 peptide solution } \\ \text { PEG6000 } & \text { polyethylene glycol } 6000 \\ \text { Cm } & \text { chloramphenicol } \\ \text { MS } & \text { Murashige \& Skoog } \\ \text { Cb } & \text { Carbenicillin } \\ \text { RH } & \text { relative humidity } \\ \text { qRT-PCR } & \text { quantitative real-time PCR } \\ & \end{array}$




\section{References}

1. Choi, M.S.; Kim, W.; Lee, C.; Oh, C.S. Harpins, multifunctional proteins secreted by gram-negative plant-pathogenic bacteria. Mol. Plant Microbe Interact. MPMI 2013, 26, 1115-1122. [CrossRef]

2. Li, P.; Lu, X.; Shao, M.; Long, J.; Wang, J. Genetic diversity of harpins from Xanthomonas oryzae and their activity to induce hypersensitive response and disease resistance in tobacco. Sci. China. Ser. C Life Sci. 2004, 47, 461-469. [CrossRef] [PubMed]

3. Sgro, G.G.; Ficarra, F.A.; Dunger, G.; Scarpeci, T.E.; Valle, E.M.; Cortadi, A.; Orellano, E.G.; Gottig, N.; Ottado, J. Contribution of a harpin protein from Xanthomonas axonopodis pv. citri to pathogen virulence. Mol. Plant Pathol. 2012, 13, 1047-1059. [CrossRef] [PubMed]

4. Zhu, W.; MaGbanua, M.M.; White, F.F. Identification of two novel hrp-associated genes in the hrp gene cluster of Xanthomonas oryzae pv. oryzae. J. Bacteriol. 2000, 182, 1844-1853. [CrossRef] [PubMed]

5. Crabill, E.; Karpisek, A.; Alfano, J.R. The Pseudomonas syringae HrpJ protein controls the secretion of type III translocator proteins and has a virulence role inside plant cells. Mol. Microbiol. 2012, 85, 225-238. [CrossRef] [PubMed]

6. Wei, Z.M.; Laby, R.J.; Zumoff, C.H.; Bauer, D.W.; He, S.Y.; Collmer, A.; Beer, S.V. Harpin, elicitor of the hypersensitive response produced by the plant pathogen Erwinia amylovora. Science 1992, 257, 85-88. [CrossRef]

7. Peng, J.L.; Bao, Z.L.; Ren, H.Y.; Wang, J.S.; Dong, H.S. Expression of harpin (xoo) in transgenic tobacco induces pathogen defense in the absence of hypersensitive cell death. Phytopathology 2004, 94, 1048-1055. [CrossRef]

8. Dong, H.P.; Peng, J.; Bao, Z.; Meng, X.; Bonasera, J.M.; Chen, G.; Beer, S.V.; Dong, H. Downstream divergence of the ethylene signaling pathway for harpin-stimulated Arabidopsis growth and insect defense. Plant Physiol. 2004, 136, 3628-3638. [CrossRef]

9. Wang, X.; Zhang, L.; Ji, H.; Mo, X.; Li, P.; Wang, J.; Dong, H. Hpa1 is a type III translocator in Xanthomonas oryzae pv. oryzae. BMC Microbiol. 2018, 18, 105. [CrossRef]

10. Krause, M.; Durner, J. Harpin inactivates mitochondria in Arabidopsis suspension cells. Molecular plant-microbe interactions. MPMI 2004, 17, 131-139. [CrossRef]

11. Alfano, J.R.; Collmer, A. The type III (Hrp) secretion pathway of plant pathogenic bacteria: Trafficking harpins, Avr proteins, and death. J. Bacteriol. 1997, 179, 5655-5662. [CrossRef] [PubMed]

12. Ji, Z.; Song, C.; Lu, X.; Wang, J. Two coiled-coil regions of Xanthomonas oryzae pv. oryzae harpin differ in oligomerization and hypersensitive response induction. Amino Acids 2011, 40, 381-392. [CrossRef] [PubMed]

13. Wang, X.Y.; Song, C.F.; Miao, W.G.; Ji, Z.L.; Wang, X.; Zhang, Y.; Zhang, J.H.; Hu, J.S.; Borth, W.; Wang, J.S. Mutations in the N-terminal coding region of the harpin protein Hpa1 from Xanthomonas oryzae cause loss of hypersensitive reaction induction in tobacco. Appl. Microbiol. Biotechnol. 2008, 81, 359-369. [CrossRef] [PubMed]

14. Li, X.; Han, L.; Zhao, Y.; You, Z.; Dong, H.; Zhang, C. Hpa1 harpin needs nitroxyl terminus to promote vegetative growth and leaf photosynthesis in Arabidopsis. J. Biosci. 2014, 39, 127-137. [CrossRef]

15. Ji, H.; Dong, H. Key steps in type III secretion system (T3SS) towards translocon assembly with potential sensor at plant plasma membrane. Mol. Plant Pathol. 2015, 16, 762-773. [CrossRef]

16. Li, L.; Wang, H.; Gago, J.; Cui, H.; Qian, Z.; Kodama, N.; Ji, H.; Tian, S.; Shen, D.; Chen, Y.; et al. Harpin Hpa1 interacts with aquaporin PIP1;4 to promote the substrate transport and photosynthesis in Arabidopsis. Sci. Rep. 2015, 5, 17207. [CrossRef]

17. Oh, J.; Kim, J.G.; Jeon, E.; Yoo, C.H.; Moon, J.S.; Rhee, S.; Hwang, I. Amyloidogenesis of type III-dependent harpins from plant pathogenic bacteria. J. Biol. Chem. 2007, 282, 13601-13609. [CrossRef]

18. Alfano, J.R.; Bauer, D.W.; Milos, T.M.; Collmer, A. Analysis of the role of the Pseudomonas syringae pv. syringae HrpZ harpin in elicitation of the hypersensitive response in tobacco using functionally non-polar hrpZ deletion mutations, truncated HrpZ fragments, and hrmA mutations. Mol. Microbiol. 1996, 19, 715-728. [CrossRef]

19. Lee, J.; Klessig, D.F.; Nürnberger, T. A harpin binding site in tobacco plasma membranes mediates activation of the pathogenesisrelated gene HIN1 independent of extracellular calcium but dependent on mitogen-activated protein kinase activity. Plant Cell 2001, 13, 1079-1093. [CrossRef]

20. Lupas, A.N.; Gruber, M. The structure of alpha-helical coiled coils. Adv. Protein Chem. 2005, 70, 37-78.

21. Lupas, A. Prediction and analysis of coiled-coil structures. Methods Enzymol. 1996, 266, 513-525. [PubMed]

22. Woolfson, D.N. Coiled-Coil Design: Updated and upgraded. Sub Cell. Biochem. 2017, 82, 35-61.

23. Woolfson, D.N.; Alber, T. Predicting oligomerization states of coiled coils. Protein Sci. Publ. Protein Soc. 1995, 4, $1596-1607$. [CrossRef] [PubMed]

24. Woolfson, D.N.; Bartlett, G.J.; Bruning, M.; Thomson, A.R. New currency for old rope: From coiled-coil assemblies to $\alpha$-helical barrels. Curr. Opin. Struct. Biol. 2012, 22, 432-441. [CrossRef] [PubMed]

25. Harbury, P.B.; Zhang, T.; Kim, P.S.; Alber, T. A switch between two-, three-, and four-stranded coiled coils in GCN4 leucine zipper mutants. Science 1993, 262, 1401-1407. [CrossRef] [PubMed]

26. Burkhard, P.; Stetefeld, J.; Strelkov, S.V. Coiled coils: A highly versatile protein folding motif. Trends Cell Biol. 2001, 11, 82-88. [CrossRef]

27. Dutta, K.; Alexandrov, A.; Huang, H.; Pascal, S.M. pH-induced folding of an apoptotic coiled coil. Protein Sci. A Publ. Protein Soc. 2001, 10, 2531-2540. [CrossRef]

28. Burkhard, P.; Meier, M.; Lustig, A. Design of a minimal protein oligomerization domain by a structural approach. Protein Sci. A Publ. Protein Soc. 2000, 9, 2294-2301. [CrossRef] 
29. Meier, M.; Lustig, A.; Aebi, U.; Burkhard, P. Removing an interhelical salt bridge abolishes coiled-coil formation in a de novo designed peptide. J. Struct. Biol. 2002, 137, 65-72. [CrossRef]

30. Newman, J.R.; Wolf, E.; Kim, P.S. A computationally directed screen identifying interacting coiled coils from Saccharomyces cerevisiae. Proc. Natl. Acad. Sci. USA 2000, 97, 13203-13208. [CrossRef]

31. Delahay, R.M.; Frankel, G. Coiled-coil proteins associated with type III secretion systems: A versatile domain revisited. Mol. Microbiol. 2002, 45, 905-916. [CrossRef] [PubMed]

32. Wang, X.; Li, M.; Zhang, J.; Zhang, Y.; Zhang, G.; Wang, J. Identification of a key functional region in harpins from Xanthomonas that suppresses protein aggregation and mediates harpin expression in E. coli. Mol. Biol. Rep. 2007, 34, 189-198. [CrossRef]

33. Nadendla, S.R.; Rani, T.S.; Vaikuntapu, P.R.; Maddu, R.R.; Podile, A.R. Harpin Pss encapsulation in chitosan nanoparticles for improved bioavailability and disease resistance in tomato. Carbohydr. Polym. 2018, 199, 11-19. [CrossRef] [PubMed]

34. Ger, M.J.; Chen, C.H.; Hwang, S.Y.; Huang, H.E.; Podile, A.R.; Dayakar, B.V.; Feng, T.Y. Constitutive expression of hrap gene in transgenic tobacco plant enhances resistance against virulent bacterial pathogens by induction of a hypersensitive response. MPMI 2002, 15, 764-773. [CrossRef]

35. Chuang, H.W.; Harnrak, A.; Chen, Y.C.; Hsu, C.M. A harpin-induced ethylene-responsive factor regulates plant growth and responses to biotic and abiotic stresses. Biochem. Biophys. Res. Commun. 2010, 402, 414-420. [CrossRef]

36. Zhang, L.; Xiao, S.; Li, W.; Feng, W.; Li, J.; Wu, Z.; Gao, X.; Liu, F.; Shao, M. Overexpression of a Harpin-encoding gene hrf1 in rice enhances drought tolerance. J. Exp. Bot. 2011, 62, 4229-4238. [CrossRef]

37. Liu, H.; Wang, Y.; Zhou, X.; Wang, C.; Wang, C.; Fu, J.; Wei, T. Overexpression of a harpin-encoding gene popW from Ralstonia solanacearum primed antioxidant defenses with enhanced drought tolerance in tobacco plants. Plant Cell Rep. 2016, 35, 1333-1344. [CrossRef]

38. Ma, Q.; Xia, Z.; Cai, Z.; Li, L.; Cheng, Y.; Liu, J.; Nian, H. GmWRKY16 enhances drought and salt tolerance through an ABA-mediated pathway in Arabidopsis thaliana. Front. Plant Sci. 2018, 9, 1979. [CrossRef]

39. Jin, Y.; Pan, W.; Zheng, X.; Cheng, X.; Liu, M.; Ma, H.; Ge, X. OsERF101, an ERF family transcription factor, regulates drought stress response in reproductive tissues. Plant Mol. Biol. 2018, 98, 51-65. [CrossRef]

40. Miao, W.; Wang, X.; Li, M.; Song, C.; Wang, Y.; Hu, D.; Wang, J. Genetic transformation of cotton with a harpin-encoding gene

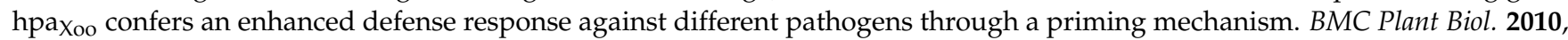
10, 67. [CrossRef]

41. Shao, M.; Wang, J.; Dean, R.A.; Lin, Y.; Gao, X.; Hu, S. Expression of a harpin-encoding gene in rice confers durable nonspecific resistance to Magnaporthe grisea. Plant Biotechnol. J. 2008, 6, 73-81. [CrossRef] [PubMed]

42. Peng, Y.; van Wersch, R.; Zhang, Y. Convergent and divergent signaling in PAMP-triggered immunity and effector-triggered immunity. Mol. Plant Microbe Interact. MPMI 2018, 31, 403-409. [CrossRef] [PubMed]

43. Zipfel, C. Early molecular events in PAMP-triggered immunity. Curr. Opin. Plant Biol. 2009, 12, 414-420. [CrossRef] [PubMed]

44. Bethke, G.; Pecher, P.; Eschen-Lippold, L.; Tsuda, K.; Katagiri, F.; Glazebrook, J.; Scheel, D.; Lee, J. Activation of the Arabidopsis thaliana mitogen-activated protein kinase MPK11 by the flagellin-derived elicitor peptide, flg22. Mol. Plant Microbe Interact. MPMI 2012, 25, 471-480. [CrossRef] [PubMed]

45. Seybold, H.; Trempel, F.; Ranf, S.; Scheel, D.; Romeis, T.; Lee, J. Ca ${ }^{2+}$ signalling in plant immune response: From pattern recognition receptors to $\mathrm{Ca}^{2+}$ decoding mechanisms. N. Phytol. 2014, 204, 782-790. [CrossRef]

46. Robert-Seilaniantz, A.; Grant, M.; Jones, J.D. Hormone crosstalk in plant disease and defense: More than just jasmonate-salicylate antagonism. Annu. Rev. Phytopathol. 2011, 49, 317-343. [CrossRef]

47. Pieterse, C.M.; Leon-Reyes, A.; Van der Ent, S.; Van Wees, S.C. Networking by small-molecule hormones in plant immunity. Nat. Chem. Biol. 2009, 5, 308-316. [CrossRef]

48. Pieterse, C.M.; Van der Does, D.; Zamioudis, C.; Leon-Reyes, A.; Van Wees, S.C. Hormonal modulation of plant immunity. Annu. Rev. Cell Dev. Biol. 2012, 28, 489-521. [CrossRef]

49. Glazebrook, J. Contrasting mechanisms of defense against biotrophic and necrotrophic pathogens. Annu. Rev. Phytopathol. 2005, 43, 205-227. [CrossRef]

50. Niu, L.; Yang, J.; Zhang, J.; He, H.; Xing, G.; Zhao, Q.; Guo, D.; Sui, L.; Zhong, X.; Yang, X. Introduction of the harpin Xooc-encoding gene hrf2 in soybean enhances resistance against the oomycete pathogen Phytophthora sojae. Transg. Res. 2019, 28, 257-266. [CrossRef]

51. Meng, F.-H.; Song, C.-F.; Ji, Z.-L.; Wang, J.-S. Effect of transgenic tobacco expressing Harpin Xoo $_{o n}$ and its N-terminal sequence on TMV resistance. J. Nanjing Agric. Univ. 2007, 30, 47-52.

52. Sharma, V.; Goel, P.; Kumar, S.; Singh, A.K. An apple transcription factor, MdDREB76, confers salt and drought tolerance in transgenic tobacco by activating the expression of stress-responsive genes. Plant Cell Rep. 2019, 38, 221-241. [CrossRef] [PubMed] 